\title{
Facies architecture and diagenesis of Belgian Late Frasnian carbonate mounds
}

\author{
Frédéric Boulvain* \\ Géologie-Pétrologie-Géochimie, B20, Université de Liège, Sart Tilman, B-4000 Liège, Belgium
}

Received 6 June 2000; accepted 15 May 2001

\begin{abstract}
Late Frasnian Petit-Mont Member carbonate mounds occur in the southern part of the Dinant Synclinorium and in the Philippeville Anticline (SW Belgium). These mounds are 30 to $80 \mathrm{~m}$ thick and 100 to $250 \mathrm{~m}$ in diameter. They are embedded in shale, nodular shale and argillaceous limestone. Based on facies mapping of 14 buildups and related off-mound sediments, these mounds typically started from below the photic and storm wave base zones and builtup into shallow water environments. Above an argillaceous limestone substrate, the first carbonate mound facies consists of spiculitic wackestone with stromatactis (PM1), which becomes progressively enriched in crinoids and corals (PM2), then in peloids, stromatoporoids and cyanobacteria (PM3). PM4 consists of algal-coral-peloid wackestone and packstone with green algae and thick algal coatings. A core of algal and microbial bindstone (PM5) sporadically occurs within large mounds. The uppermost part of these mounds may show a recurrence of facies PM2 and PM1. PM1 to PM3 are coloured red by hematite derived from microaerophilic iron bacteria; PM4 and PM5 are grey. The transition from the aphotic to the cyanobacterial photic zone is recorded in the succession PM2-PM3; the transition from the cyanobacterial to the green algal photic zone is recorded by PM3-PM5. Storm wave base was reached within PM3 and fair-weather wave base within PM5. This paleobathymetric interpretation suggests a depth of $100-150 \mathrm{~m}$ during initial establishment of PM1. Three types of mounds can be distinguished on the basis of geometry and facies architecture: (1) "Les Bulants"-type mounds display a continuous vertical facies succession (PM2-3-4-5) and low relief; (2) although exhibiting the same facies succession as "Les Bulants", "Les Wayons"-type mounds show a distinct relief with steep flanks and bioclastic talus; (3) "St.-Rémy" mounds consist exclusively of PM1 and PM2, bioclastic flank deposits are not observed. From (1) to (3), these mound types represent successive deepening down a ramp. Biostratigraphic correlation on a regional scale provides good evidence that relative sea-level changes largely controlled lateral and vertical transitions of facies. Beyond that, hypoxic conditions are indicated by the sponge and iron-bacteria consortium in lower parts of the mounds. This is in agreement with the general assumption of stratified water masses during Late Frasnian, preceding the prominent Lower Kellwasser crisis. Cementation began with a radiaxial synsedimentary cement. A fringe of meteoric phreatic cement, initially nonluminescent, then with a bright orange luminescence, occurs in all mounds. It is contemporaneous with a nonluminescent pervasive cement of grainstones deposited in littoral areas. Differentiation between the (reducing) mounds and the (oxidizing) littoral area resulted from better aquifer circulation in sedimentary bodies close to the recharge area. Late burial cements occlude all the remaining porosity and are contemporaneous with the opening of the Variscan fracture system. C 2001 Elsevier Science B.V. All rights reserved.
\end{abstract}

Keywords: Carbonate mound; Reef; Facies; Frasnian; Belgium; Palaeoceanography

\footnotetext{
${ }^{*}$ Tel.: +32-4-366-22-52; fax: +32-4-366-29-21.

E-mail address: fboulvain@ulg.ac.be (F. Boulvain).
} 


\section{Introduction}

Among the various Palaeozoic carbonate mounds known throughout the world (e.g., Bosence and Bridges, 1995; Monty, 1995; Pratt, 1995; Bourque, 1997), the Frasnian carbonate mounds of Belgium are probably the earliest studied. This remarkable interest carried by generations of geologists derives from the number and quality of outcrop: currently 69 carbonate mounds are known and the majority were actively quarried for marble. Consequently, several hundred square meters of sawn sections are accessible for examination.

The combination of extraordinary outcrop exposures and a well-documented Devonian stratigraphy makes Frasnian carbonate mounds in Belgium of international significance (e.g., Tsien, 1975). This paper is devoted to the Petit-Mont Member carbonate mounds (Late Frasnian). It illustrates various facies architectures, interprets mound palaeoenvironments and assesses the possible relationship between evolution of carbonate mounds and changes in palaeoceanographic setting of the sedimentary basin.

\subsection{Frasnian mounds of Belgium: a short summary of research history}

Dewalque (1868) first recognized the "reefal" character of Belgian Frasnian mounds. After stratigraphic subdivision by Maillieux (1913, 1926), Delhaye (1913) recognized a distinct vertical succession of lithofacies within these mounds; however, it was Dumon (1932) who related this succession to bathymetric variation. He named these facies according to terms of quarry men (from the base to the top: "griotte fleurie", "griotte", "royal rosé", "rouge royal foncé",

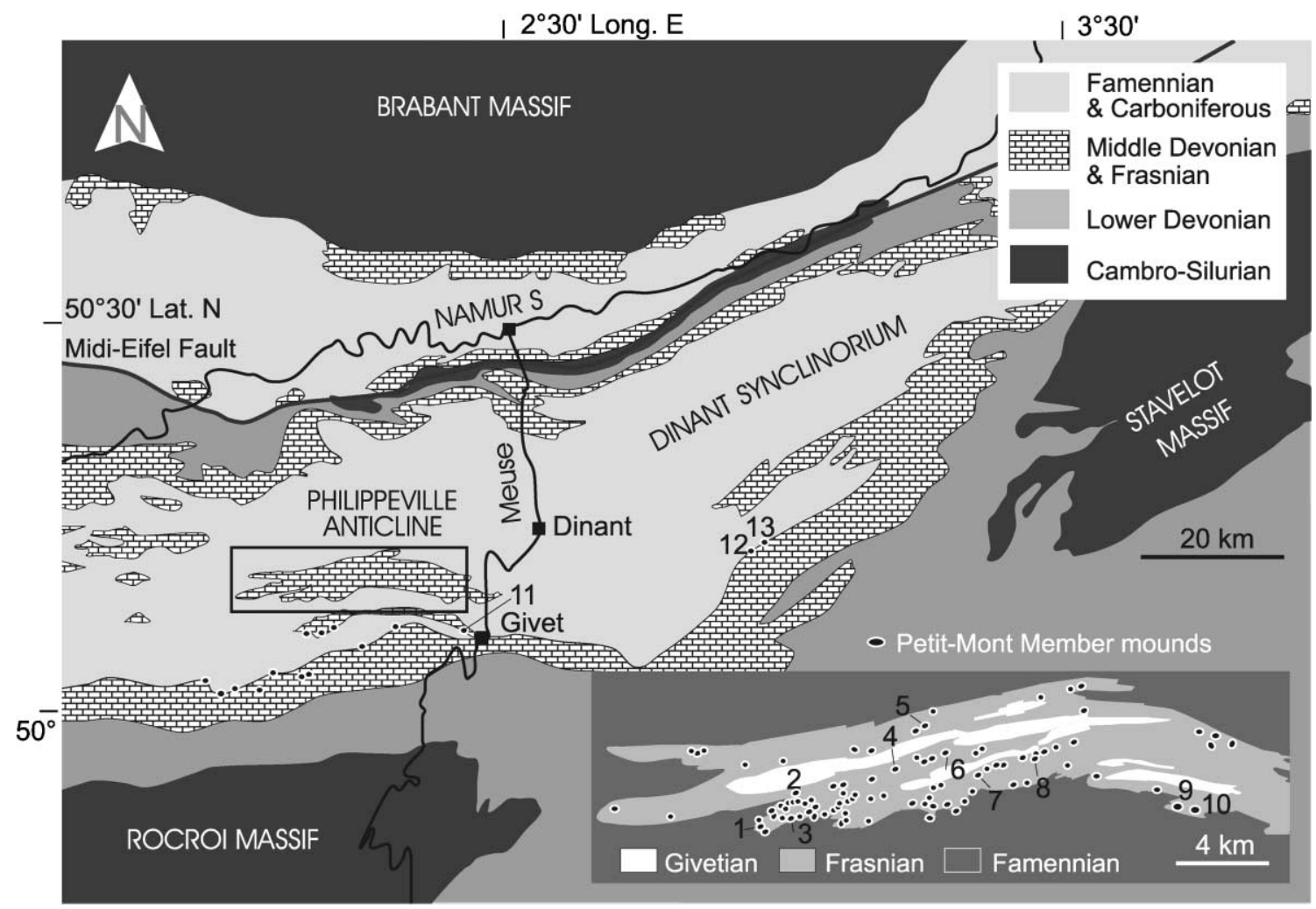

Fig. 1. Simplified geological map of southern Belgium with locations of studied carbonate mounds and sections. See Table 1 for name and grid references of Petit-Mont Member mounds. 
"rouge royal byzantin", "gris", "rouge royal supérieur", "gros rouge"). Lecompte $(1936,1959)$ realized that the Frasnian bioherms are developed in relatively deep water under conditions of subsidence. His facies zonation (successively lower red zone with corals and stromatactis; median pink or grey zone with corals, brachiopods, crinoids, stromatoporoids and algae; and upper red zone with corals), was focussed on bathymetric and hydrodynamic criteria (below turbulent zone for the red zones and within turbulent zone for the grey or pink zone). According to Tsien (1975, 1980), reefal biofacies were built in the wave action zone (red and pink limestone with corals and cyanobacteria; red and pink limestone with corals and stromatactis; grey limestone with corals and cryptalgal structures), whereas others formed below the wave action zone (red limestone with stromatactis; pink limestone with Renalcis). Tsien (1980) considered that these mud mounds are developed in the photic zone, near the wave action zone, in an environment where argillaceous sedimentation was significant. He also showed that the slopes of buildups were partly oversteepened by differential compaction between buildup limestone and argillaceous nonbiohermal sediments. Monty et al. (1982) and Monty and Van Laer (1988) asserted that the majority of cavity cements, like the micrite in buildups, were of bacterial origin and that the presence of microbial gel allowed the development of steep slopes and significant relief. They concluded that the buildups are developed below wave base and below the photic zone.

\section{Stratigraphic context}

Recently, the lithostratigraphy of the Belgian Frasnian has been revised (Boulvain et al., 1999). Three stratigraphic levels bear Frasnian carbonate mounds (Figs. 1, 2). These are, in stratigraphic order, the Arche, the Lion and the Petit-Mont Members. In the Philippeville Anticline, only the upper level contains mounds (Petit-Mont Member, Plate 1A). The other carbonate mound levels are replaced laterally by bedded limestone, locally with back-reef character. At the northern border of the Dinant Synclinorium and in the Namur Syncline (Figs. 1, 2), the entire

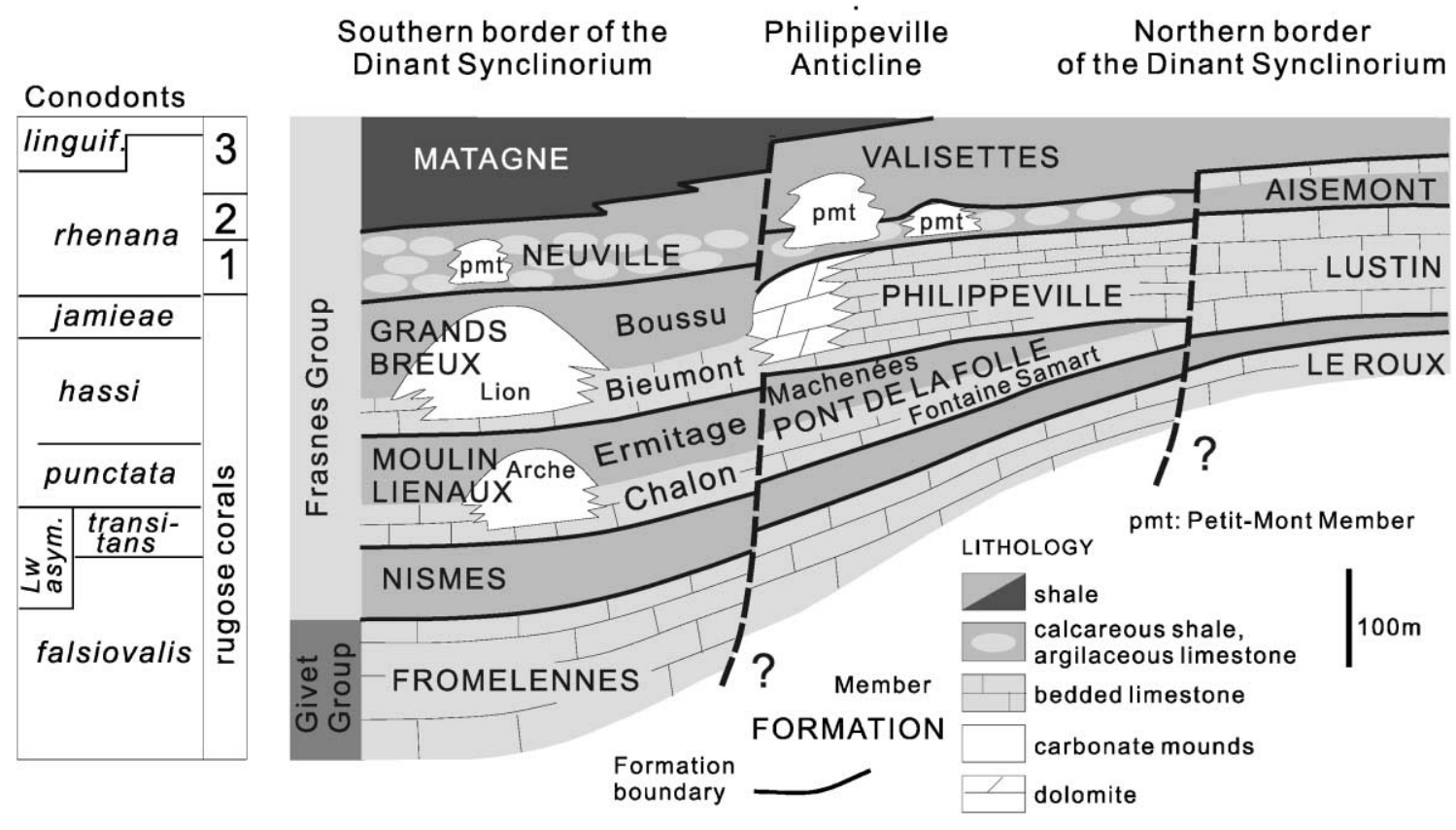

Fig. 2. Schematic meridian stratigraphical section of the Frasnian sedimentary basin in Belgium (before Variscan orogeny). Conodonts after Bultynck et al. (1998). 

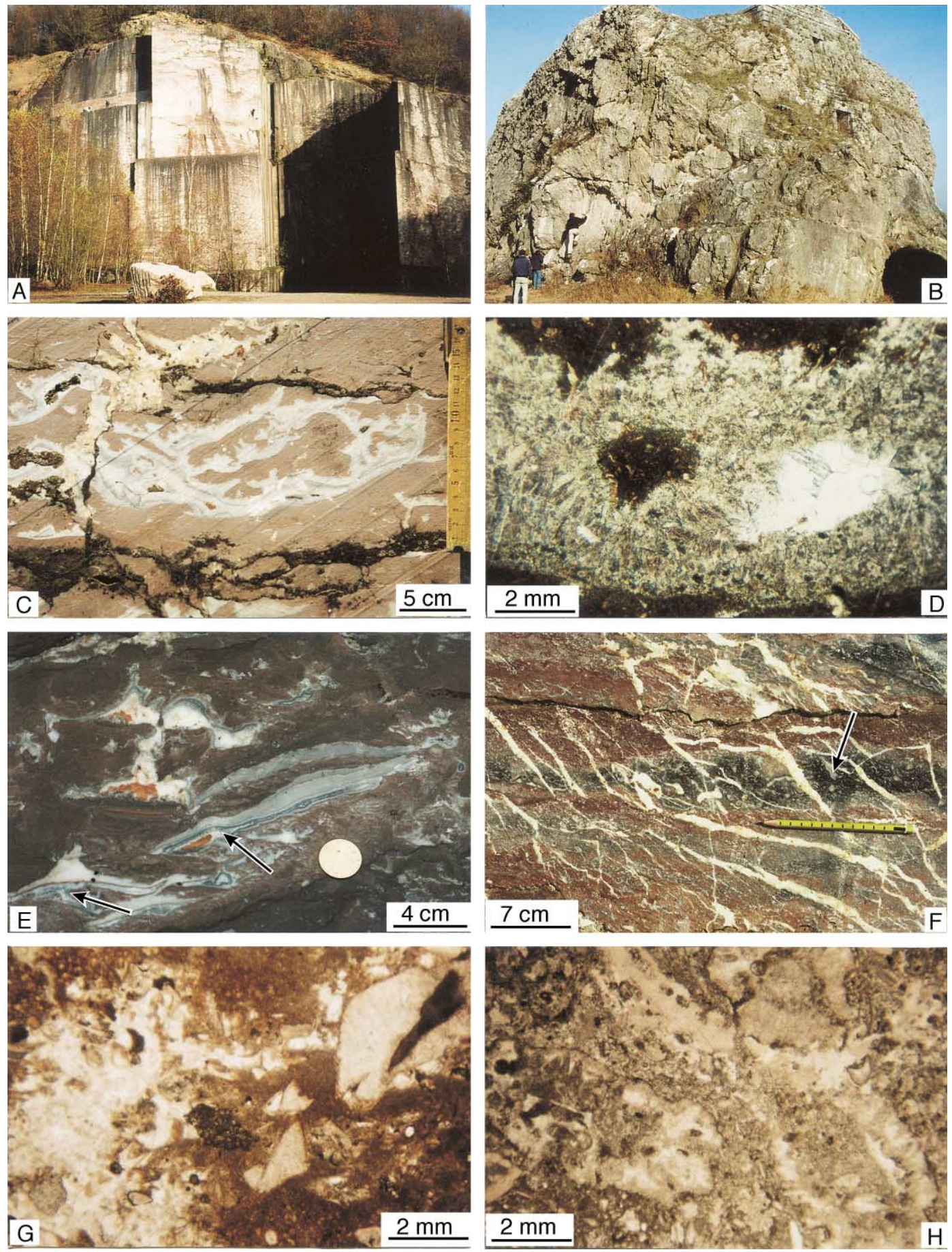
Table 1

Grid references of studied Petit-Mont Member carbonate mounds. Belgian Lambert 1972 coordinate system

\begin{tabular}{lllll}
\hline No. (Fig. 1) & Quarry & Map & $X$ & $Y$ \\
\hline 1 & Beauchâteau & IGNB 57/3-4 & 158,300 & 94,300 \\
2 & Les Bulants & IGNB 57/3-4 & 159,775 & 95,625 \\
3 & Tapoumont & IGNB 57/3-4 & 159,600 & 94,675 \\
4 & Tienne à 1'Gatte & IGNB 58/1-2 & 163,650 & 96,625 \\
5 & Les Croisettes & IGNB 58/1-2 & 164,625 & 98,150 \\
6 & Les Maquettes & IGNB 58/1-2 & 165,650 & 97,150 \\
7 & Les Wayons & IGNB 58/1-2 & 166,800 & 96,250 \\
8 & Rochefontaine & IGNB 58/1-2 & 169,450 & 96,925 \\
9 & Hautmont & IGNB 58/1-2 & 175,200 & 95,000 \\
10 & Petit-Mont & IGNB 58/1-2 & 175,625 & 95,000 \\
11 & Fort-Condé & IGNB 58/3-4 & 181,100 & 92,100 \\
12 & St.-Rémy & IGNB 59/3-4 & 211,625 & 97,775 \\
13 & Tiers-Cocrai & IGNB 54/7-8 & 212,500 & 99,000 \\
\hline
\end{tabular}

Frasnian consists of bedded limestone and argillaceous strata.

The Petit-Mont Member carbonate mounds (see Table 1 for grid references) date from the top of the Early rhenana base of Late rhenana conodont zones (Bultynck et al., 1998). Based on the succession of three rugose coral biozones (Coen-Aubert, 1982; Boulvain and Coen-Aubert, 1989), a high-resolution biostratigraphy is available within mounds as well as off-mound sediments.

\section{Area of study, material and methods}

Among the 69 carbonate mounds currently listed in the study area, nine buildups from the Philippeville Anticline (Beauchâteau, Fig. 3, Plate 1A, Les Bulants, Fig. 4A, Tienne à l'Gatte, Fig. 4B, Les Wayons, Fig. 5A, Petit-Mont, Fig. 5B, Rochefontaine, Hautmont, Fig. 6, Les Croisettes, Tapoumont) together with three carbonate mounds from the southern border of the Dinant Synclinorium (Fort-Condé, Plate 1B, St.-
Rémy, Tiers Cocrai, Fig. 7) were examined for this study. Several sections in each buildup were described bed by bed, and more than 2000 thin sections were produced. Polished slabs were examined under a binocular microscope. Sections were also studied in peri- and off-mound environments at the southern border of the Dinant Synclinorium (Frasnes) and in the Philippeville Anticline (Neuville railway sections, Fig. 4A). Coeval sections were also studied in the internal zones of the Frasnian platform at the northern border of the Dinant Synclinorium (Lustin, Crupet, Fig. 8), at the southern border of the Namur Syncline (Aisemont, Fig. 8) and at the northern border of the Namur Syncline (Huccorgne, Fig. 8).

Diagenesis studies were performed on the PetitMont, Hautmont, Beauchâteau, Les Maquettes, Les Wayons and Maudoux-Mousty carbonate mounds in the Philippeville Anticline, on the Tiers-Cocrai, St.Rémy and St.-Martin mounds at the southern border of the Dinant Synclinorium and on sections Lustin and Crupet at the northern border of the Dinant Synclinorium. Several hundred thin sections were used for cathodoluminescence. Surface staining (Dickson method) and microprobe analysis (Camebax probe) were conducted at the C.A.M.S.T., Universite Catholique de Louvain. Isotopic analyses of $\mathrm{C}$ and $\mathrm{O}$ were conducted at Vrije Universiteit Brussel on a Finnigan Mat Delta E mass spectrometer (Boulvain et al., 1992). Two series of ten analyses were carried out for each sample.

\section{Facies units of Petit-Mont Member carbonate mounds}

\subsection{Premound facies (Table 2)}

Exposed in the Petit-Mont (Fig. 5B), Les Bulants, Tienne à l'Gatte (Fig. 4), Les Wayons (Fig. 5A)

Plate 1. (A) Upper part of the Beauchâteau carbonate mound, near Senzeilles (Philippeville Anticline). For sketch of the mound, see Fig. 3. The height of the outcrop is $30 \mathrm{~m}$. (B) Fort-Condé mud mound, near Givet (southern border of the Dinant Synclinorium). (C) Red limestone with stromatactis (PM1), Les Croisettes quarry, Vodecée. (D) Microfacies PM1a: mudstone with stromatactis. Radiaxial cement is rich in black impurities. Note the peloids at the base of the stromatactis. Les Bulants quarry, BL 15, plane polarized light. (E) Red limestone with stromatactis, corals, crinoids (PM2). Supported cavities filled with radiaxial cement occur below lamellar corals (arrows). Beauchâteau carbonate mound, Senzeilles. (F) Pink limestone with corals, crinoids, brachiopods, stromatactis, fenestrae, stromatoporoids and nebuloids (arrow) (PM3). Les Bulants quarry, $29 \mathrm{~m}$ above the base of the section, Fig. 4A. (G) Microfacies PM3b: wackestone with stromatactoid fenestrae, crinoids, fenestellids, and peloids. Tapoumont quarry, TP 44, plane polarized light. (H) Microfacies PM4b. Packstone with peloids and Trelonella. Tapoumont quarry, TPG2a, plane polarized light. 


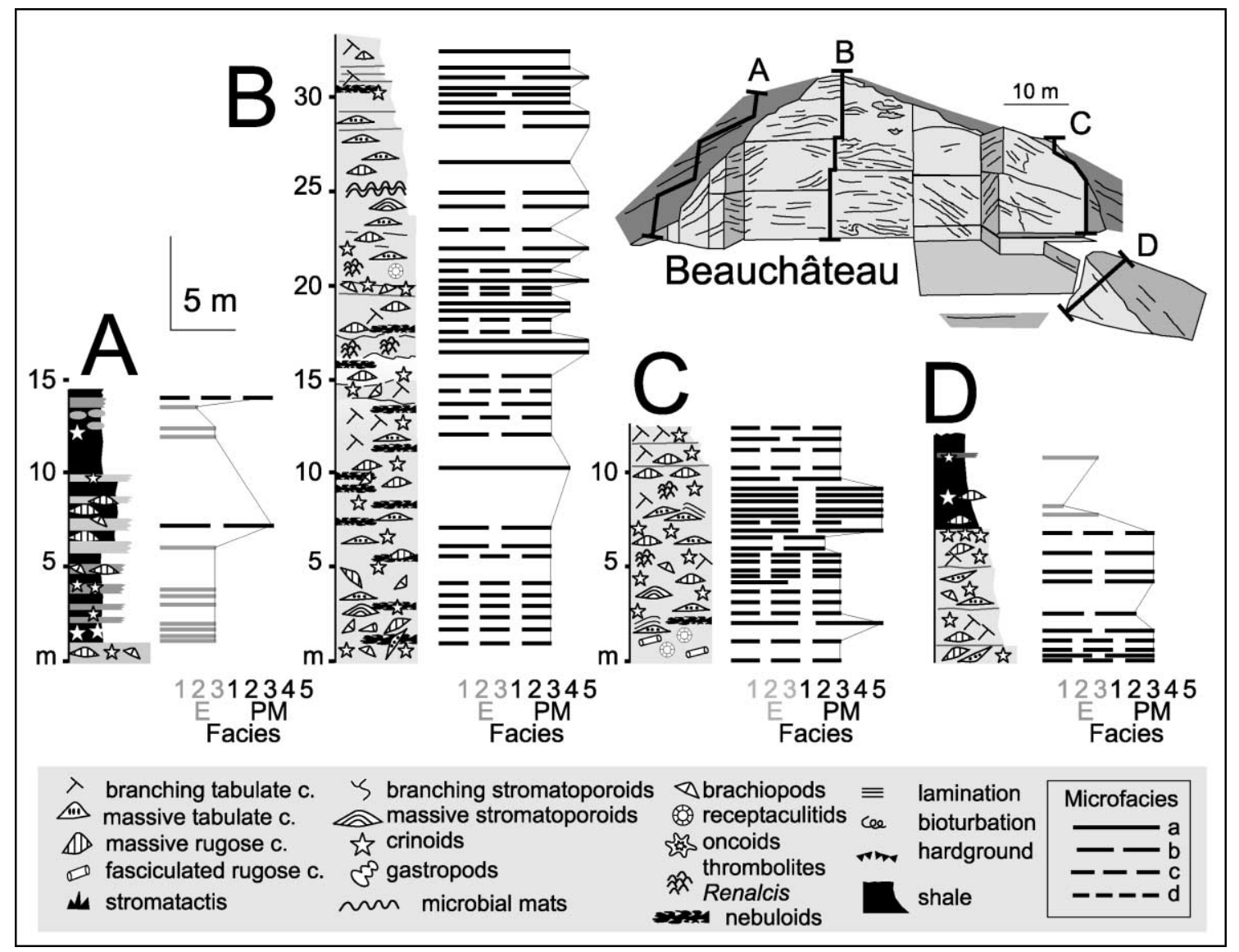

Fig. 3. Correlated logs of the Beauchâteau mound (Philippeville Anticline), with distribution of facies and microfacies.

(Philippeville Anticline) and Fort-Condé (Fig. 7) quarries (southern border of the Dinant Synclinorium), this facies consists of greenish-grey argillaceous limestone and nodular shale containing brachiopods and crinoids (E2). Nodules are of $\mathrm{cm}-\mathrm{dm}$ scale and commonly are irregular. Four microfacies are present (Table 2). Sponges (lyssakine hexactinellids and tetractinomorph demosponges, Termier et al., 1981) are abundant below mound bases.

\subsection{Mound facies (Table 3)}

Five facies are recognized, corresponding to five fossil assemblages.

PM1. Red limestone with stromatactis (Plate 1C): The intense red pigmentation is the consequence of a hematite content up to $5 \% \mathrm{FeO}$. The occurrence of stromatactis is variable. Stromatactis may be grouped in $\mathrm{m}$-scale beds forming a reticulate structure and exceeding $50 \%$ of the rock. Stromatactis may exceed $50 \mathrm{~cm}$ in length, but generally diminish in size towards more argillaceous zones. Stromatactis are cemented by inclusion-rich radiaxial calcite (Plate 1D). The cement surmounts various types of internal sediment (laminar microspar; microspar with vermiform texture of Pratt, 1982; peloids and pseudosparite; microbial mats; ooids with a microsparitic cortex). A strict geometrical relationship between spicular networks and stromatactis does not exist: spicules can overlie, penetrate or form concentrations below stromatactis. In addition to stromatactis, $\mathrm{mm}$-scale fenestrae with granular sparitic cement are common. Sponges are abundant (e.g., tetractinellids, hexactinellids and other nonrigid demosponges with a simple 


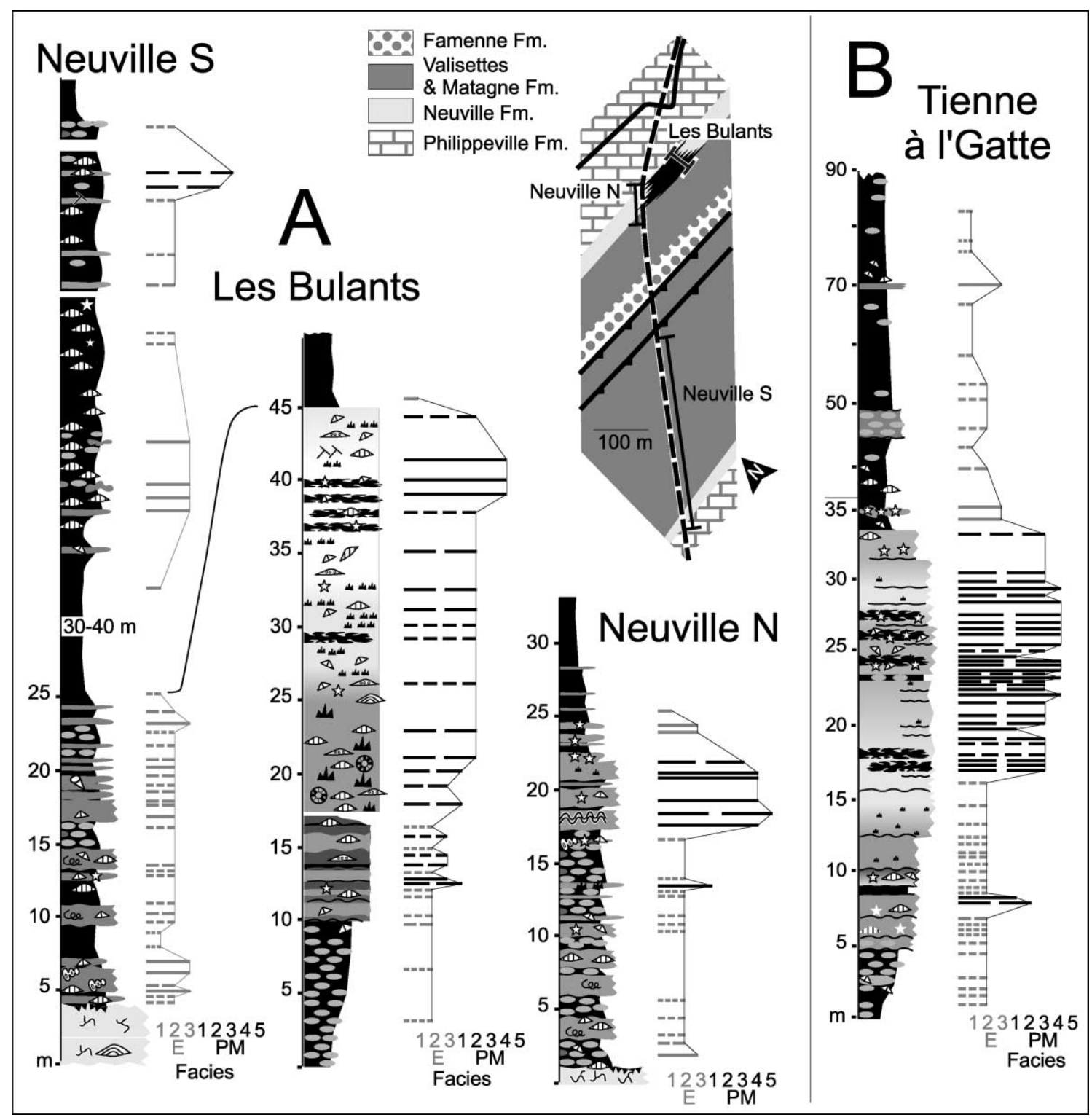

Fig. 4. (A) Correlated logs of the Les Bulants mound and Neuville $\mathrm{N}$ and $\mathrm{S}$ railway sections, with distribution of facies and microfacies. (B) Log of the Tienne à l'Gatte quarry, with distribution of facies and microfacies (Philippeville Anticline). See Fig. 3 for legend.

monaxone assemblage of spicules). Matrix is microsparitic to pseudosparitic. Three microfacies are distinguished (Table 3).

PM2. Red limestone with stromatactis, lamellar corals, crinoids: This facies differs from the former by the addition of crinoids and lamellar corals such as Alveolites and Phillipsastrea. Dm-scale stromatactis and $\mathrm{cm}$-scale stromatactoid fenestrae with granular cement are abundant. Supported cavities filled with radiaxial cement typically occur below lamellar organisms (Plate 1E). Two microfacies are distinguished (Table 3).

PM3. Pink limestone with corals, crinoids, brachiopods, stromatactis, fenestrae and lamellar stro- 


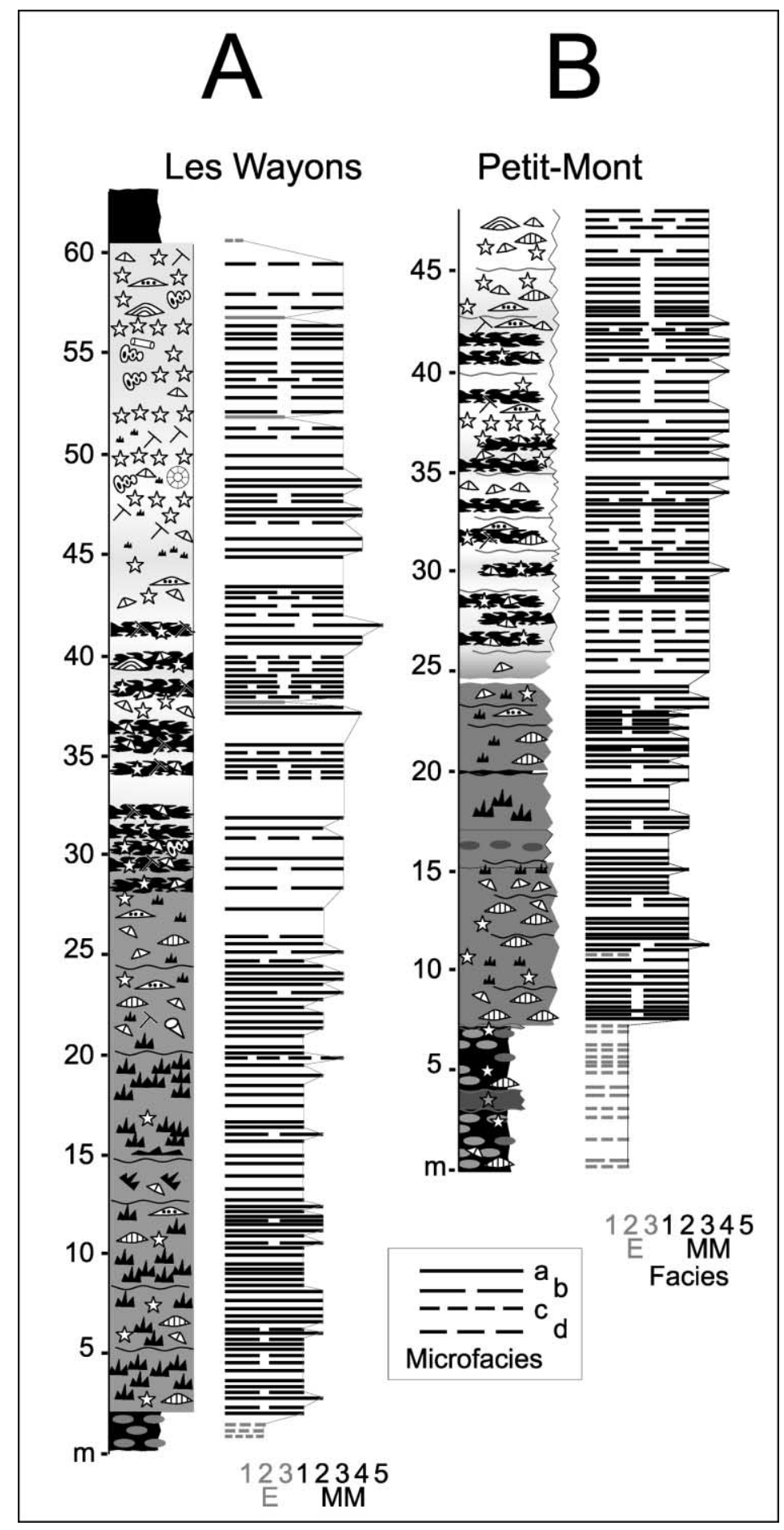

Fig. 5. (A) Log of the Les Wayons mound (Philippeville Anticline), with distribution of facies and microfacies. (B) Log of the Petit-Mont quarry, with distribution of facies and microfacies. See Fig. 3 for legend. 


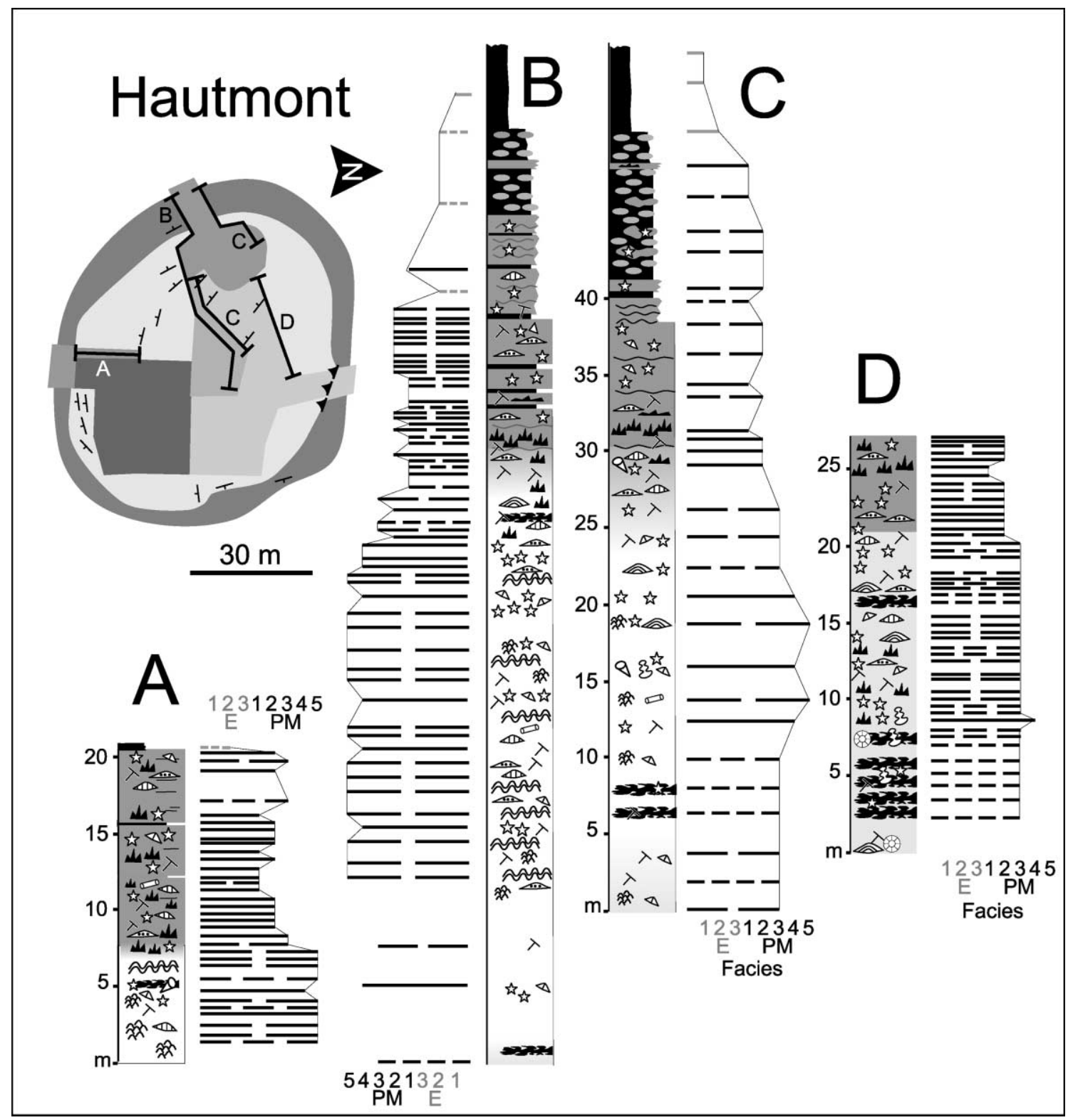

Fig. 6. Correlated logs of the Hautmont quarry (Philippeville Anticline), with distribution of facies and microfacies. See Fig. 3 for legend.

matoporoids (Plate 1F): This facies shows dm-scale beds rich in mm-scale stromatactoid fenestrae, crinoids, brachiopods and other bioclasts intercalated with beds containing sparse fenestrae, corals and subordinate stromatoporoids. Corals are generally tabular (Alveolites, Phillipsastrea, Thecostegites), branching (Thamnopora, Senceliaepora) or fascicu- late (Thamnophyllum); solitary rugose corals are also present. Receptaculites is locally abundant. This facies is locally interbedded with argillaceous bioclastic units rich in crinoids, coral fragments and brachiopods. Enigmatic structures consisting of $\mathrm{dm}$-scale pockets or beds of dark grey radiaxial cement containing brachiopods and crinoids occur (Plate 1F). These 


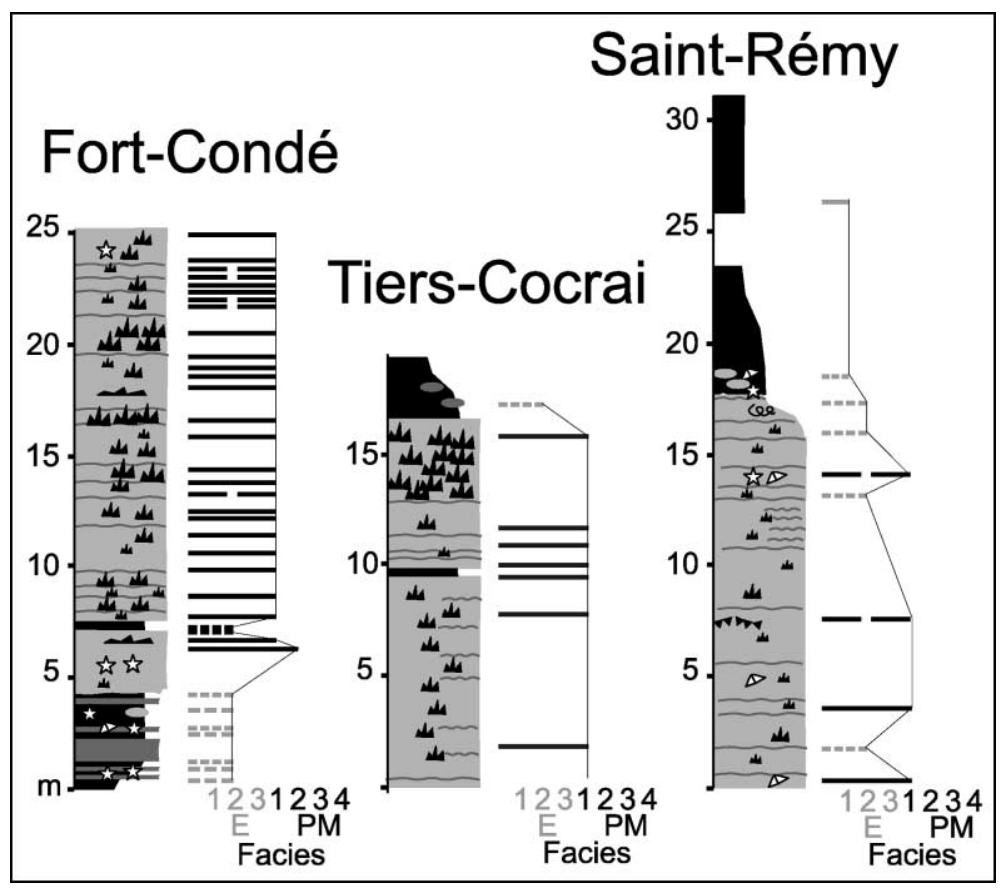

Fig. 7. Logs of the Fort-Condé, St.-Rémy, and Tiers Cocrai mounds (S of Dinant Synclinorium), with distribution of facies and microfacies. See Fig. 3 for legend.

particular structures (herein called "nebuloids") may pass laterally by reduction in the proportion of cement into a network of $\mathrm{cm}$-scale stromatactis or fenestrae. Cyanobacteria form partial coatings around particles, and peloids are common and irregular. Four microfacies are distinguished (Table 3, Plate 1G).

PM4. Grey limestone with mm-scale fenestrae, branching tabulate corals and brachiopods: This facies is devoid of stromatactis. Two microfacies (Table 3, Plate $1 \mathrm{H})$ are characterized by common peloids and encrusting cyanobacteria. Coatings are generally composite, consisting of an association of various algae and bryozoans. Green algae (Trelonella, Radiosphaeroporella) are abundant (Mamet and Boulvain, 1992).

PM5. Grey limestone with corals, stromatoporoids, microbial mats, thrombolites: This facies forms massive limestone with stylolites. Dm-to-m scale growth cavities cemented by granular spar are abundant. Breccia is locally present. The fauna is dominated by subspherical coral colonies (Hankaxis, Phillipsastrea, Alveolites), Thamnopora, brachiopods and subordinate branching stromatoporoids (Amphipora). Renalcis is locally abundant. Thrombolitic structures and microbial mats are present. Three microfacies are distinguished (Table 3, Plate 2A,B). Thrombolites form digitated masses consisting of 30 to $60 \mu \mathrm{m}$ peloids, with a diffuse border, dispersed in pseudospar (cf. "structure grumeleuse", Cayeux, 1935; Flügel, 1982). Within thrombolites, Renalcis is associated with Palaeomicrocodium (Plate 2A). Microbial mats consist of the same structure grumeleuse as described above, alternating with thin microsparitic laminae (Plate 2B). Irregular peloids and fragments of microbial mats are abundant. Most organisms (including Palaeomicrocodium) are strongly encrusted by Sphaerocodium, Girvanella, Wetheredella, and microbial mats.

\subsection{Flank and postmound facies (Table 2)}

Flank deposits are well exposed in Beauchâteau (Fig. 3A), Les Bulants, Neuville $\mathrm{N}$ and $\mathrm{S}$ (Fig. 4A), Petit-Mont (Fig. 5B) (Philippeville Anticline), FortCondé (Fig. 7) and Frasnes at the southern border of the Dinant Synclinorium. Postmound strata are exposed in Beauchâteau, Les Bulants, Les Maquettes, 


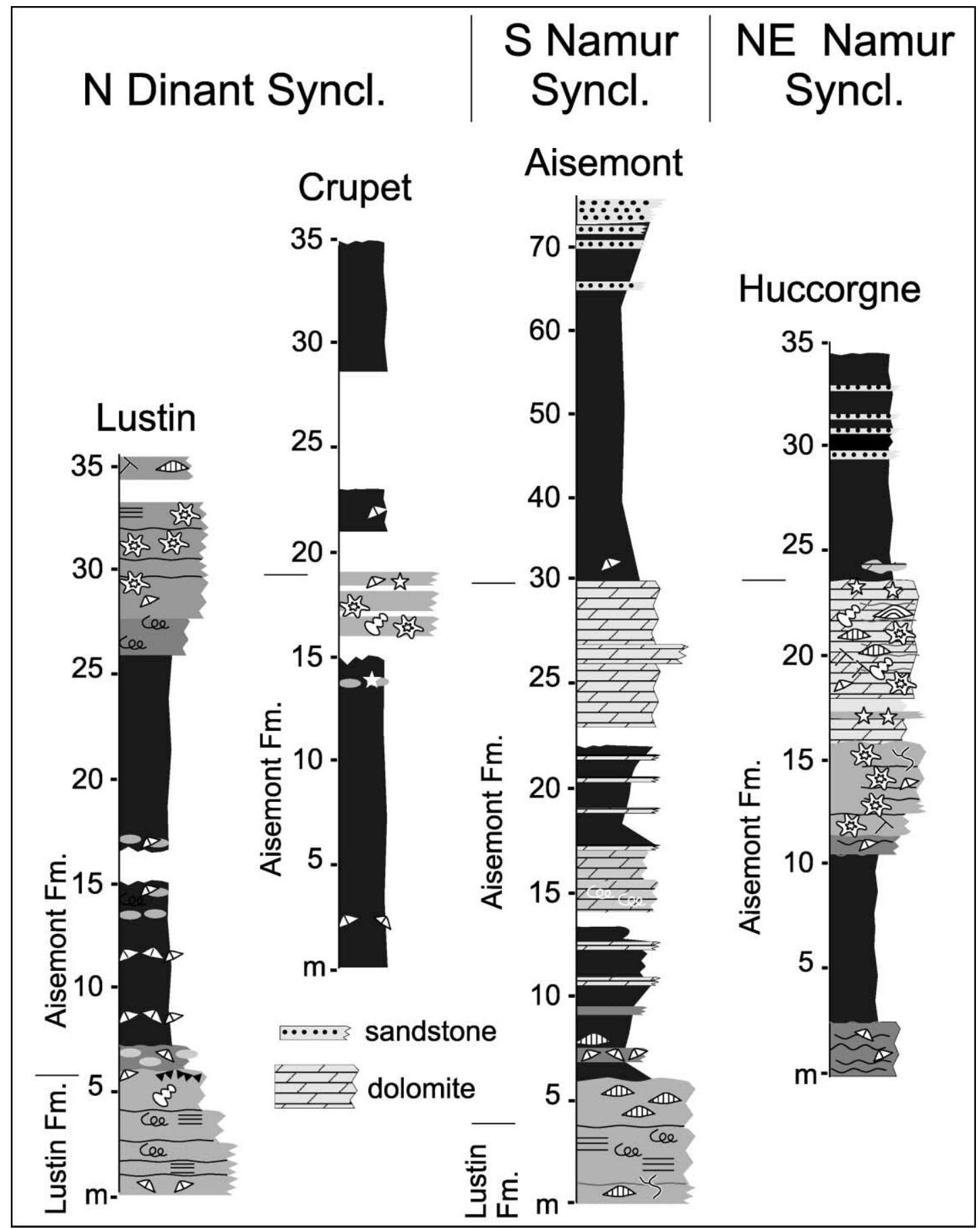

Fig. 8. Logs of Lustin, Crupet, Aisemont and Huccorgne sections. See Fig. 3 for legend. 
Table 2

Premound, off-mound and postmound facies and microfacies

\begin{tabular}{|c|c|c|c|c|}
\hline Facies & Microfacies (a) & Microfacies (b) & Microfacies (c) & Microfacies (d) \\
\hline $\begin{array}{l}\text { Dark grey limestone } \\
\text { with crinoids and } \\
\text { bioclasts (E3). }\end{array}$ & $\begin{array}{l}\text { Grainstone, packstone with } \\
\text { crinoids (fenestellids, peloids, } \\
\text { coral fragments, brachiopods, } \\
\text { ostracodes, trilobites, } \\
\text { cricoconarids, pelecypods). }\end{array}$ & & & \\
\hline $\begin{array}{l}\text { Greenish-gray } \\
\text { argillaceous limestone } \\
\text { and nodular shale } \\
\text { with brachiopods, } \\
\text { crinoids (E2). }\end{array}$ & $\begin{array}{l}\text { Microsparitic mudstone } \\
\text { with mm-scale } \\
\text { subhorizontal burrows } \\
\text { (Ostracodes, cricoconarids, } \\
\text { brachiopods). }\end{array}$ & $\begin{array}{l}\text { Floatstone with } \\
\text { lamellar Alveolites } \\
\text { and Phillipsastrea, } \\
\text { sponge spicules. }\end{array}$ & $\begin{array}{l}\text { Wackestone, packstone } \\
\text { with crinoids, brachiopods } \\
\text { and sponge spicules } \\
\text { (bryozoans, ostracodes, } \\
\text { coral fragments, lithoclasts, } \\
\text { trilobites, cricoconarids). }\end{array}$ & $\begin{array}{l}\text { Wackestone with } \\
\text { sponge spicules. } \\
\text { Irregular or } \\
\text { stromatactoid } \\
\text { mm-to-cm-scale } \\
\text { fenestrae. }\end{array}$ \\
\hline $\begin{array}{l}\text { Greenish to brownish } \\
\text { shale, with sporadic } \\
\text { limestone nodules (E1). }\end{array}$ & Laminar shales. & $\begin{array}{l}\text { Bioturbated shales } \\
\text { with horizontal } \\
\text { burrows, ostracodes } \\
\text { and cricoconarids. }\end{array}$ & $\begin{array}{l}\text { Shales with beds of } \\
\text { pelecypods, brachiopods, } \\
\text { bioclasts. }\end{array}$ & \\
\hline
\end{tabular}

Hautmont (Fig. 6), Tapoumont, Tienne à l'Gatte (Fig. 4B) (Philippeville Anticline) and Tiers-Cocrai (Fig. 7) at the southern border of the Dinant Synclinorium. Flank facies consists of argillaceous limestone and nodular shale containing brachiopods and crinoids (E2; analogous to facies below the mounds) and of fine shale (E1), locally containing lenses and banks of crinoidal or bioclastic limestone (E3).

E3. Dark grey limestone with crinoids and bioclasts. This unit forms dm-thick lenses or beds, with a slightly undulating planar upper surface and an erosive lower surface (Plate 2C). Upper surfaces locally were used as substrates by corals.

E1. Green to brown shale. Limestone nodules are sporadic. In some cases, nodules coalesce to produce irregular beds. This unit includes three microfacies (Table 2).

\section{Architecture of carbonate mounds}

Measured sections within individual mounds are correlated on the basis of bedding planes. In sections $\mathrm{A}$ and $\mathrm{B}$ at Beauchâteau (Fig. 3), the correlation is based on the first appearance of A. asymmetricus (Tourneur, 1982). In Les Bulants section, lateral to the Neuville $\mathrm{N}$ and $\mathrm{S}$ sections (Fig. 4A), the correlations are lithostratigraphic; i.e., the top limestone of the Philippeville Formation and basal shale of the Valisettes Formation.

\subsection{How many types of mounds?}

A total of three distinct mound types are recognized in this study (Fig. 9). In the Philippeville Anticline, two types of mound occur. The first type ("Les Wayons", from Les Wayons quarry) consists of roughly hemispherical limestone bodies, $60-80 \mathrm{~m}$ thick with a diameter of 150-250 m (Plate 1A). The lower parts of these mounds are included in E2 argillaceous limestone (Neuville Formation) and their upper parts in E1 shale (Valisettes Formation). The second type ("Les Bulants") corresponds to flattened buildups, $30-40 \mathrm{~m}$ thick and $100-250 \mathrm{~m}$ wide, included in E2 argillaceous limestone (Neuville Formation). At the southern border of the Dinant Synclinorium, the "Saint-Rémy"-type (Fig. 1) mounds are lenticular buildups about $30 \mathrm{~m}$ thick (FortCondé), included in E2 sediments of the Neuville Formation. Further east, these buildups exceed $40 \mathrm{~m}$ in thickness at Saint-Rémy and Tiers-Cocrai. Only facies PM1 and PM2 are represented in these mounds. In the Barvaux area, the few known buildups seem to have developed above the Neuville Formation (Coen et al., 1977), within the shale of the Valisettes Formation.

\section{2. “Les Bulants"-type carbonate mounds}

Two buildups of this type are known: Les Bulants and Tienne à l'Gatte (Fig. 4A, B). The 
Table 3

Mound facies and microfacies

\begin{tabular}{|c|c|c|c|c|}
\hline Facies & Microfacies (a) & Microfacies (b) & Microfacies (c) & Microfacies (d) \\
\hline $\begin{array}{l}\text { Grey limestone } \\
\text { with corals, } \\
\text { stromatoporoids, } \\
\text { microbial mats, } \\
\text { thrombolites (PM5) }\end{array}$ & $\begin{array}{l}\text { Thrombolitic } \\
\text { bafflestone } \\
\text { with Renalcis, } \\
\text { ostracodes, peloids, } \\
\text { (Palaeomicrocodium) }\end{array}$ & $\begin{array}{l}\text { Bindstone with } \\
\text { microbial mats, } \\
\text { peloids, corals, } \\
\text { stromatoporoids, } \\
\text { Renalcis, Sphaerocodium, } \\
\text { Girvanella, corals, } \\
\text { stromatoporoids, crinoids, } \\
\text { fenestellids, ostracodes, } \\
\text { (Nuia, Trelonella) }\end{array}$ & $\begin{array}{l}\text { Brecciated packstone } \\
\text { and rudstone with } \\
\text { elements of }(b) .\end{array}$ & \\
\hline $\begin{array}{l}\text { Grey limestone } \\
\text { with fenestrae, } \\
\text { branching tabulate } \\
\text { corals and } \\
\text { brachiopods (PM4) }\end{array}$ & $\begin{array}{l}\text { Wackestone with } \\
\text { peloids, branching } \\
\text { tabulates, fenestrae, } \\
\text { Sphaerocodium, } \\
\text { Girvanella, Trelonella, } \\
\text { other green algae, } \\
\text { bryozoans, crinoids, } \\
\text { gastropods, } \\
\text { brachiopods, (branching } \\
\text { stromatoporoids). }\end{array}$ & $\begin{array}{l}\text { Packstone, grainstone } \\
\text { with peloids, Sphaerocodium, } \\
\text { Girvanella, Trelonella, } \\
\text { other green algae, } \\
\text { Wetheredella. }\end{array}$ & & \\
\hline $\begin{array}{l}\text { Pink limestone } \\
\text { with corals, crinoids, } \\
\text { brachiopods, } \\
\text { stromatactis, } \\
\text { fenestrae and lamellar } \\
\text { stromatoporoids (PM3). }\end{array}$ & $\begin{array}{l}\text { Wackestone with } \\
\text { stromatactis, sponge } \\
\text { spicules and peloids }\end{array}$ & $\begin{array}{l}\text { Wackestone, floatstone } \\
\text { with stromatactis, } \\
\text { fenestrae, crinoids, } \\
\text { fenestellids, peloids, } \\
\text { ostracodes, brachiopods, } \\
\text { gastropods, corals, } \\
\text { (pelecypods, stromatoporoids, } \\
\text { Rectangulina, Sphaerocodium, } \\
\text { Girvanella). }\end{array}$ & $\begin{array}{l}\text { Packstone, bindstone } \\
\text { with crinoids, fenestellids, } \\
\text { peloids, corals, } \\
\text { stromatoporoids, } \\
\text { (Sphaerocodium, Girvanella). }\end{array}$ & $\begin{array}{l}\text { Grainstone, rudstone } \\
\text { with brachiopods, peloids, } \\
\text { crinoids, (Sphaerocodium, } \\
\text { Girvanella). = "nebuloids" }\end{array}$ \\
\hline $\begin{array}{l}\text { Red limestone } \\
\text { with stromatactis, } \\
\text { lamellar corals, } \\
\text { crinoids (PM2). }\end{array}$ & $\begin{array}{l}\text { Wackestone with } \\
\text { stromatactis, spicules, } \\
\text { crinoids, corals, } \\
\text { ostracodes, } \\
\text { (brachiopods, } \\
\text { gastropods, pelecypods, } \\
\text { Rectangulina, } \\
\text { Kleinbergella). }\end{array}$ & $\begin{array}{l}\text { Packstone or wackestone with } \\
\text { crinoids, spicules, corals, } \\
\text { brachiopods, fenestellids, } \\
\text { ostracodes and Nanicella. }\end{array}$ & & \\
\hline $\begin{array}{l}\text { Red limestone with } \\
\text { stromatactis (PM1). }\end{array}$ & $\begin{array}{l}\text { Mudstone with } \\
\text { stromatactis and } \\
\text { sponges. }\end{array}$ & $\begin{array}{l}\text { Mudstone with } \\
\text { stromatactis, sponge } \\
\text { spicules, ostracodes, } \\
\text { Egosiella }^{\mathrm{a}} \text {, Kleinbergella }\end{array}$ & $\begin{array}{l}\text { Wackestone with } \\
\text { stromatactoid fenestrae, } \\
\text { Egosiella, spicules, } \\
\text { (bryozoans, brachiopods, } \\
\text { trilobites, ostracodes) }\end{array}$ & \\
\hline
\end{tabular}

Taxa in () have minor abundance.

${ }^{\text {a }}$ Branching tabulate coral.

b Microproblematica, cf. Mamet and Boulvain (1992).

first section is located $100 \mathrm{~m}$ away from the core of the mound, whereas the second is peripheral. The two sections of Neuville facilitate the study of the peri-biohermal environment (Neuville $\mathrm{N}$ is $175 \mathrm{~m}$ and Neuville $\mathrm{S}$ is more than $800 \mathrm{~m}$ away from Les Bulants mound). The buildups overlie argillaceous limestone (E2), which also interdigitates with mound strata.

The first biohermal facies are PM2 with subordinate PM1. The mound, at this stage of development, was only $100-150 \mathrm{~m}$ wide; $10 \mathrm{~m}$ higher, PM3 developed. The most abundant microfacies is PM3b. 

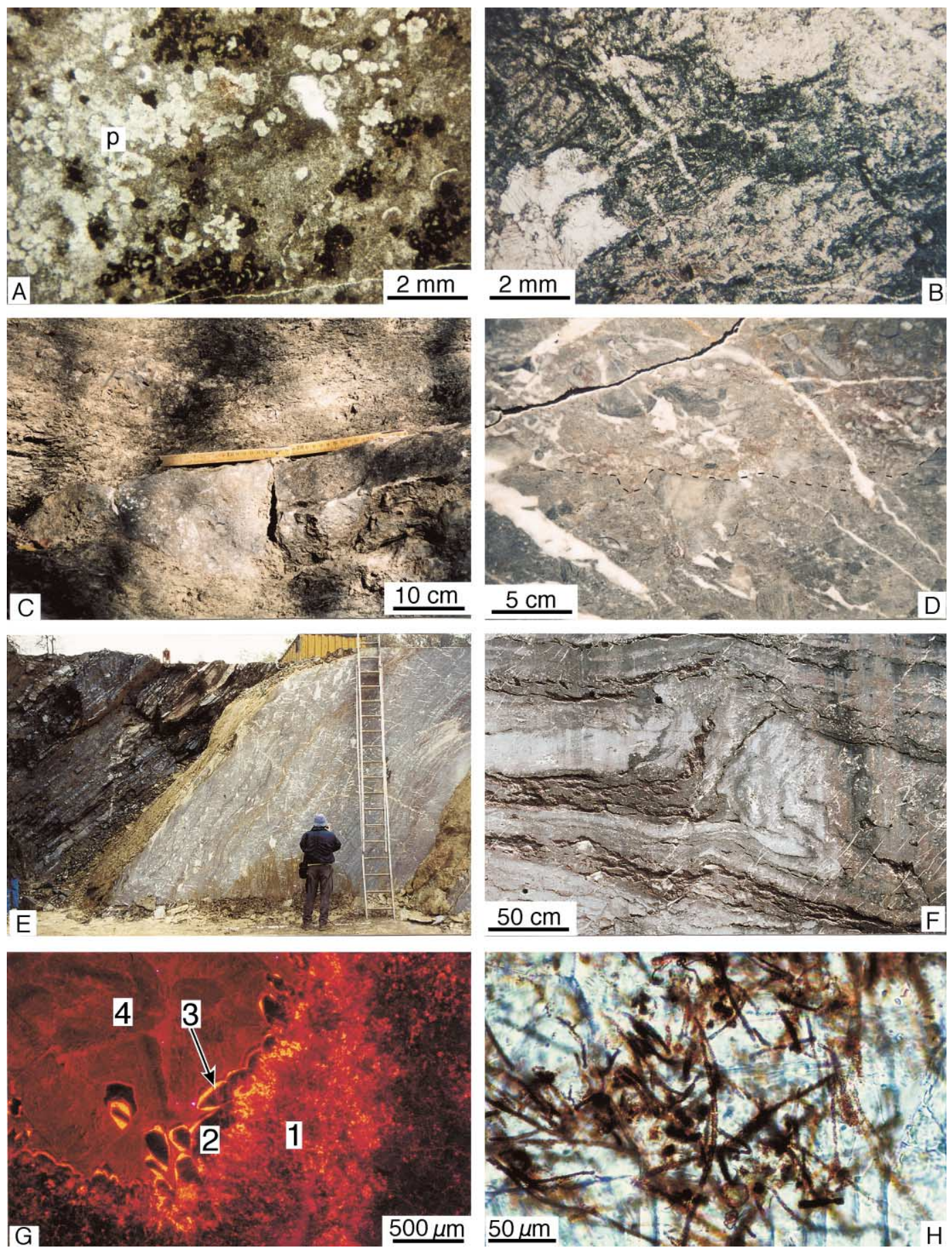


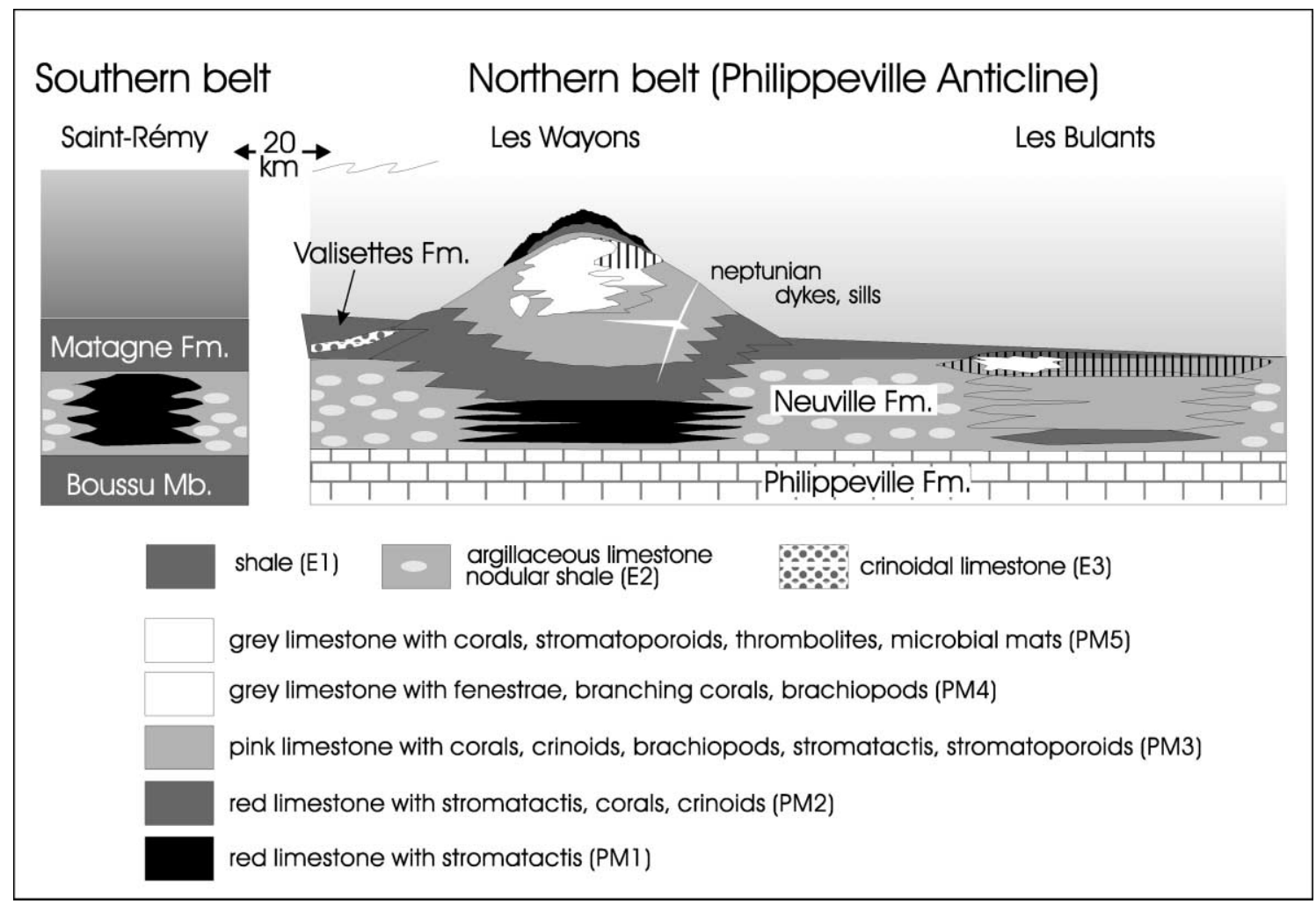

Fig. 9. Sedimentological models of "Les Wayons", "Les Bulants" and "Saint-Rémy" types carbonate mounds.

Nebuloids are common (PM3d). This facies, from 10 to $20 \mathrm{~m}$ thick, is slightly more laterally extensive than PM2 (it is found at Tienne à l'Gatte, but not at Neuville N). The upper $10 \mathrm{~m}$ of the mound consists of PM4, with local recurrences of underlying facies. This grey limestone is more laterally extensive than the preceding facies. It occurs in the Neuville $\mathrm{N}$ section above facies E2. Locally, in the upper part of the mound, lenses of PM5 are observed. In the upper few meters of the mounds, PM3 reappears.
Only some crinoidal grainstone lenses overlie the carbonate mound before transition to the shale (E1) of the Valisettes Formation. Geopetal features from Les Bulants and Tienne à l'Gatte sections indicate sedimentary slope not exceeding $10^{\circ}$.

\section{3. "Les Wayons"-type carbonate mounds}

These occur at Les Wayons (Fig. 5A) and PetitMont (complete section, central and peripheral zone,

Plate 2. (A) Microfacies PM5a. Thrombolitic bafflestone with Renalcis, Palaeomicrocodium (p) and ostracodes. Beauchâteau quarry, SZ38, plane polarized light. (B) Microfacies PM5b. Bindstone with microbial mats, Sphaerocodium. Hautmont quarry, HML1, plane polarized light. (C) Dark grey limestone with crinoids and bioclasts (E3) in shale, on the flank of Beauchâteau carbonate mound. $2 \mathrm{~m}$ above the base of section A, Fig. 3. (D) Hardground (dashed line) separating grey limestone with corals, stromatoporoids, thrombolites, microbial mats (PM5) from pink limestone with corals, crinoids, brachiopods, stromatactis, fenestrae and stromatoporoids (PM3). Upper part of the Petit-Mont carbonate mound, near Vodelée. (E) Shale and argillaceous limestone covering the flanks of Les Maquettes carbonate mound, Villers-le Gambon. (F) Slump structure, affecting the pink limestone with corals, crinoids, brachiopods, stromatactis, fenestrae, and stromatoporoids (PM3). Base of section B (Fig. 3), Beauchâteau carbonate mound. (G) Typical diagenetic sequence in stromatactis; (1) radiaxial cement, (2) automorphic nonluminescent calcite with (3) a bright orange fringe and (4) xenomorphic calcite with dull orange luminescence. Les Bulants quarry, BL15, cathodoluminescence. $(\mathrm{H})$ Iron bacteria in sparite. Rochefontaine quarry, RFX, plane polarized light. 
Fig. 5B), Hautmont (upper part, central zone, Fig. 6), Beauchâteau (Fig. 3) and Tapoumont (upper part, peripheral-central zone transition).

Above facies E2, which is enriched in sponges near the mounds, a section about $20 \mathrm{~m}$ thick consists of PM1 and PM2. This interval is overlain by about $15 \mathrm{~m}$ of PM3. At the microfacies level, a lateral differentiation is observed: in the peripheral zone, PM3b dominates. Corals are rare in comparison to crinoids and recurrences of PM2 are rather common. In the more central zone, PM3b is regularly interrupted by PM3c. Nebuloids are common. At Tapoumont, 20-30-cmthick nebuloids are superimposed repeatedly within a 10-m-thick interval. Dm-thick beds of bioclastic limestone (E3) appear in the surrounding shale. Geopetal features show sedimentary slopes of up to $10^{\circ}$.

In the overlying section, a clear lateral differentiation is observed at the microfacies and facies levels. Thus, in the peripheral zone, PM3 continues vertically over some $20 \mathrm{~m}$ and changes laterally, towards the flanks, to PM2. In the central zone, $30-40$ m of PM5 and PM4 are equivalent. A lateral zonation is observed at the microfacies level, with in the central position, PM5b and brecciated equivalent, while laterally, interdigitated with PM3, m-scale lenses of
PM5a are observed. The diameter of the central zone is about $50 \mathrm{~m}$. The mound reached its maximum diameter at this stratigraphic level. This laterally differentiated unit is also characterized by significant variations in thickness. In Beauchâteau, there is 50\% thickness reduction between sections B and C (Fig. 3). Strong sedimentary slopes of up to $35^{\circ}$ are observed in this part of the mound. Above the central zone (thus surmounting PM4 and 5) and slightly overstepping on the periphery, overlying a hardground, PM2, or more rarely PM1 or PM3 recurs (Plate 2D). These facies then pass gradually upward first to argillaceous limestone (E2) (Plate 2E), locally enriched in crinoids (E3), then to shale (E1).

\section{4. "Saint-Rémy"-type carbonate mounds}

The three studied buildups (Fort-Condé, SaintRémy, Tiers Cocrai, Fig. 7) consist mainly of PM1, with lenses of PM2 and of crinoids and brachiopods. The mounds do not show any facies succession. Their thickness varies (approximately $35 \mathrm{~m}$ for Fort-Condé, Plate 1B; more than $40 \mathrm{~m}$ with a diameter greater than $100 \mathrm{~m}$ for St.-Rémy, and a lateral extension of more than $300 \mathrm{~m}$ for Tiers-Cocrai). There is no evidence for

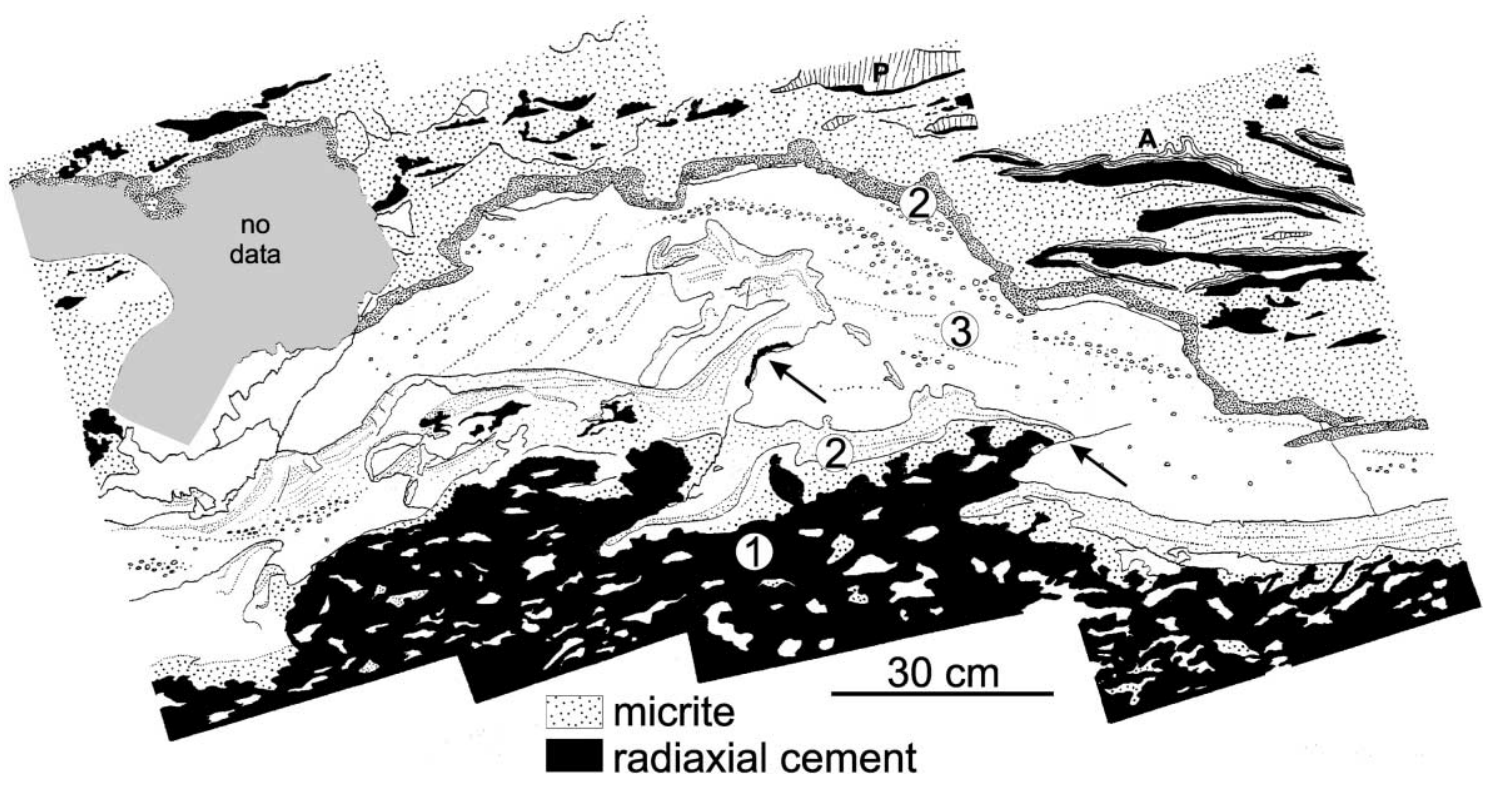

Fig. 10. Sketch of a horizontal fracture in red limestone with stromatactis, corals, and crinoids (PM2). Note the small reverse faults (arrows) affecting the internal sediments. The chronological succession of internal sediments is: (1) radiaxial spar, (2) several generations of microspar and microbial mats, and (3) crinoidal grainstone. (P) Phillipsastrea, (A) Alveolites. Les Croisettes mound (Vodecée). 
significant peripheral slopes, nor of interdigitation with off-mound facies.

\subsection{Cavities, fractures, early deformation of sediment}

Zebra fabrics (Fischer, 1964) occur sporadically in the carbonate mounds of the Petit-Mont Member. Like stromatactis, these structures are generally cemented by radiaxial spar, sometimes overlying internal sedimentation. They seem to be related to local deformation of sediment resulting from lateral compression (Boulvain, 1993).

Fractures with synsedimentary filling extend for many metres to tens of metres (Fig. 10). They occur in buildups which have the most significant sedimentary relief, e.g., the "Les Wayons" type. These fractures cut facies, truncating or irregularly circumventing the fossils. Vertical fractures are related to extension (Playford, 1981, 1984), and horizontal fractures to compression (Fig. 10). Internal filling of fractures comprises, in chronological order and in addition to the internal sediment described in connection with stromatactis (see above): (1) dm-scale spherical masses of radiaxial spar in a microsparitic matrix or in a granular sparite resembling "spar balls" of Playford (1984); (2) microbial mats; (3) various types of internal sediment: crinoidal grainstone, microspar with scattered orthoceratids, brachiopods, some encrusted lithoclasts; (4) radiaxial spar, locally rich in iron-bearing microstromatolites (Mamet and Boulvain, 1988); and (5) red or grey clays. These various types of filling were also observed in Waulsortian carbonate mounds of England (Bridges and Chapman, 1988).

In addition to deformation types listed above, some structures ascribable to slumps were observed (Plate $2 \mathrm{~F})$. Even in zones where bedding planes are close to vertical, stromatactis and stromatactoid fenestrae show horizontal bases, indicating that internal sedimentation in these cavities postdates deformation.

\section{Contemporaneous strata in the internal zones of the platform}

Internal zones of the platform are exposed in the sections of Crupet and Lustin (northern border of the Dinant Synclinorium, Aisemont (southern border of the Namur Syncline) and Huccorgne (northern border of the Namur Syncline). The succession is very similar in these various sections (Fig. 8). It consists of a first unit of argillaceous limestone with brachiopods and crinoids overlying the laminar or bioturbated limestone and loferites of the upper part of the Lustin or Huccorgne Formations, followed by a second unit of alternating bioturbated shale or argillaceous siltstone and argillaceous limestone containing brachiopods, crinoids and bioclasts. These facies are overlain by a third unit of limestone and dolomite with oncoids, corals, stromatoporoids and brachiopods. In all sections, the bioclastic content increases towards the top of the third unit, with reappearance of crinoids. The sections end with shale and argillaceous siltstone.

\section{Cementation}

\subsection{Diagenetic sequence in cm-to-dm scale cavities of carbonate mounds}

Petrographic analysis and cathodoluminescence revealed the following diagenetic sequence in cm-to$\mathrm{dm}$ scale mound cavities (Plate 2G): (1) radiaxial calcite, (2) automorphic nonluminescent calcite, succeeded by a bright orange luminescent fringe (3), (4) granular xenomorphic calcite with a dull orange luminescence, (5) iron-bearing saddle dolomite, (6) silicification.

Radiaxial calcite (1) is rich in microscopic inclusions of dolomite and organic matter: these inclusions are arranged in layers 0.5 to $1 \mathrm{~mm}$ thick, giving rise to macroscopic zoning. This radiaxial calcite shows very irregular luminescence (as described from other examples; e.g., Lohmann and Meyers, 1977; Kerans et al., 1986). Interlayering of radiaxial cement and internal sediment or microbial mats is common. Granular crystals of $50 \mu \mathrm{m}$ to $3 \mathrm{~mm}$ automorphic, nonluminescent calcite (2) shows a zoned luminescent fringe (3). The granular xenomorphic calcite (4) is locally coarsely zoned. This late stage is contemporaneous with cementation of tectonic fractures and development of pressure-solution seams. Iron-bearing saddle dolomite (5) locally replaced granular calcite. Bipyramidal quartz crystals (6) contain many inclusions of cements, which they replace. This minor 
silicification phase resemble the "quartz II" of Mountjoy and Krebs (1983).

\subsection{Diagenetic sequence in mm-scale cavities of carbonate mounds}

In small fenestrae, sponge spicules and fossils with aragonitic tests, the diagenetic sequence described above is reduced to stages (2)-(3)-(4), possibly (5). This sequence is also characteristic of syntactic cement crystallizing around crinoids.

\subsection{Diagenetic sequence in off-mound environments}

Off the carbonate mounds, fenestrae contain xenomorphic granular calcite with dull luminescence (4), locally followed by saddle dolomite.

\subsection{Diagenetic sequence in the internal zones of the platform}

Grainstones and fenestrae of limestone of the Aisemont Formation show coarse sparitic granular cement, without inclusions, which under cathodoluminescence shows the following diagenetic sequence: (2) a drusy nonluminescent xenomorphic calcite closed intergranular pore space. Tectonic fractures contain xenomorphic granular calcite with dull luminescence (4). These fractures cut the nonluminescent cement. Saddle dolomite (5) is locally abundant.

\section{Discussion}

\subsection{Sedimentological interpretation of carbonate mound facies}

Below the carbonate mounds was a soft bioturbated substrate that was colonized by sponges, corals, branching bryozoans and some crinoids (E2). The environment was situated below the photic and wave zones. Sediment had an oxic character. This type of substrate is rather surprising if compared with published reports in which crinoidal sands (Burchette, 1981), hardgrounds (Walker and Alberstadt, 1975), lamellar corals (Maurin et al., 1981), breccia (Mountjoy and Riding, 1981) and bryozoan-trapped sediment
(Cuffey, 1977; Lees and Miller, 1985) are common mound substrates.

The first mound facies is red limestone with stromatactis (PM1). Bourque and Boulvain (1993), concluded that stromatactis formed from sponge degradation in a relatively coherent sediment. Cavities left after degradation evolved within sediment by collapse of the upper part and internal sedimentation on the base (Wallace, 1987). It seems noteworthy that in spite of the presence of sponges in argillaceous limestone below the carbonate mounds, no stromatactis are observed.

The intensity of pigmentation decreases gradually from the red limestone with stromatactis (PM1) to grey limestone (PM5). The surrounding argillaceous facies are devoid of ferruginous pigment and are low in pyrite. Two hypotheses are possible to account for the presence of this pigment: (1) trapping of hematite detrital particles on the carbonate mounds (Lecompte, 1936; Reijers, 1984) or (2) local production, possibly of microbial origin (Monty et al., 1982, Boulvain, 1993). In the red matrix, a $\mu \mathrm{m}$-scale hematitic pigment occurs among crystals of microspar. In early cemented cavities, the pigment forms possibly organically precipitated coccoids 5 to $10 \mu \mathrm{m}$ in diameter and threads 1 to $3 \mu \mathrm{m}$ in diameter (Plate $2 \mathrm{H}$ ). These structures can be referred to Siderocapsa-like and Sphaerotilus-Leptothrix-like iron bacteria. It is likely that iron-oxidizing bacteria also were present in the matrix, but that they were later partially destroyed during matrix neomorphism. The ecology of recent iron-oxidizing bacteria is well known (Van Veen et al., 1978; Ghiorse, 1984). They develop in environments where iron and manganese are available in reduced form, but where the redox potential is sufficiently high so that oxidation can occur. This is the case for oxygen-poor sediment or water (Pringsheim, 1952; Nealson, 1983). It can also be related to microenvironments (e.g., within pellets) where iron bacteria are associated with other microorganisms which maintain a low $\mathrm{O}_{2}$ concentration (Cowen and Silver, 1984).

No lateral zonation of buildups occurred during the development of PM1, except a slightly higher abundance of stromatactis in the centre of the mounds. This suggests a certain isotropy of the sedimentary environment (few currents, no significant vertical gradient). Absence of algae and the prevalence of 
muddy facies indicates a quiet environment located below photic and wave action zones. The transition between the argillaceous limestone below the mounds and this facies is abrupt and is accompanied by a reduction in biological diversity. However, the establishment of the stromatactis facies was not associated with any change in laterally equivalent facies (e.g. nodular shale, E2). The development of PM1 facies could point to a local hypoxic environment, perhaps following a strong increase in organic productivity. This hypothesis is supported by decreasing bioturbation in red limestone with stromatactis. The elimination of endofauna suggests locally reducing sediment. The ubiquitous organisms, present below the mounds, would be replaced by a sponge-microbe community whose only fossilized representatives would be stromatactis and iron-oxidizing bacteria. Byers (1977) indicated that sponges can live hypoxically.

The organic community in red limestone with stromatactis, corals, crinoids (PM2) is more diversified than in the underlying facies. This facies was primarily muddy and the presence of delicate branching forms, and of some partial encrustations, indicate low energy. Sponges were abundant, but large stromatactis are rare. The less homogeneous character of the facies could explain the replacement of the large cavities by networks of small stromatactis in the zones richest in grains. Cemented cavities located under lamellar corals could have played the role of keystones, vertically limiting the collapse of the roof of the cavities left by the degradation of sponges. This facies does not show any lateral zonation. A low energy environment, below the photic zone, is suggested.

The pink limestone with corals, crinoids, brachiopods, stromatactis, fenestrae and stromatoporoids (PM3) is faunally more diverse than the surrounding facies (E2). The presence of cyanobacteria suggests deposition close to the photic zone. The sediment is essentially microsparitic, but locally packstone and rudstone are observed, indicating temporary increases in turbulence. The concentric zonation of the "Les Wayons"-type mounds, with peripheral (PM3b) passing to central (PM3c) and nebuloids, probably corresponds to higher turbulence in the centre of the mounds.

Grey limestone with fenestrae, branching tabulate corals and brachiopods (PM4) contains the most diverse organic community. Green algae, algal peloids and symmetrical coatings are common. Intraclasts indicate synsedimentary lithification. The coarse texture and presence of green algae indicate a shallow environment, in the photic and wave action zones. The disappearance of hematite could be related to better oxygenation of water, suppressing iron-oxidizing bacteria.

Skeletal organisms in grey limestone with corals, stromatoporoids, thrombolites, microbial mats (PM5) display subspherical or encrusting morphologies. Algal and microbial coatings are complex, thick and symmetrical. This is best explained by a more agitated environment. A reduction in organic diversity is also observed. Facies PM5 is also characterized by the importance of "structure grumeleuse". In the absence of obvious sponges, these structure are generally interpreted as microbial (cf., Pratt, 1982; Tsien, 1985). Perforations and lithoclasts show that the mats were synsedimentarily cemented. The bindstones (PM5b) mark the cores of the mounds (cf., also Pratt and James, 1982) and the bafflestones (PM5a) form peripheral lenses along the contact zone with more bedded sediments (PM3), probably in fore-mound position.

Flank beds of "Les Wayons" mounds are rich in crinoidal packstone and grainstone (E3). These crinoids were probably indigenous. This type of community has commonly been reported from the flanks of Paleozoic mounds (Burchette, 1981; Pratt, 1982). These communities are developed when the mounds had relief; i.e., starting from the base of the upper part of the "Les Wayons" mounds. Crinoidal beds with planar tops and undulating bases resulted from the reworking of the bioclastic material and its transport downslope.

\subsection{Geometry and rheology of the carbonate mounds}

The two types of mounds described in the Philippeville Anticline ("Les Bulants", "Les Wayons") differ by the proportion of red limestone with stromatactis (PM1), the degree of interdigitation between carbonate mound and off-mound facies, the presence or absence of lateral facies variations, the dips of the flanks, the frequency of $\mathrm{m}$-scale and larger fractures with synsedimentary filling and the abundance of limestone with crinoids and bioclasts. These characteristics can be explained by the variable lithology of 
the surrounding sediments. A different accumulation rate between E1 and E2, certainly closer to the average mound accumulation rate in the case of E2, was responsible for the low relief of "Les Bulants" mounds. Low relief was responsible for weak lateral facies differentiation and deep interdigitations with surrounding sediment.

Contradictory inferences about the mechanical state of carbonate mound mud appear to derive from field observations. The persistence of dips as high as $35^{\circ}$ on the flanks of the upper part of the "Les Wayons" mounds, the presence of lithoclasts in the grey limestone (PM5), and the sharp distinct character of some fractures indicate early lithification. Conversely, plastic deformation of the sediment (Plate $2 \mathrm{~F}$ ), presence of overturned coral colonies, formation of zebra structures by lateral compression, scarcity of hardgrounds and of sediment borings, and the irregular character of some synsedimentary fractures indicate an absence of early lithification. It appears that the sediment was initially sufficiently ductile to permit synsedimentary deformation, yet sufficiently coherent to have maintained open cavities and significant relief. It is likely the sediment had a gel-like consistency, probably related to the presence of significant quantities of organic matter.

\subsection{Significance of facies succession and palae- oceanography}

The succession of facies and assemblages in the "Les Bulants" and "Les Wayons" mounds poses an interpretive problem (Fig. 9). Two principal models have been proposed to explain the evolution of communities of constructing organisms: the autogenic model of Walker and Alberstadt (1975) and the allogenic model inspired from the work of Lecompte (1959). Lecompte considered that the succession observed in the carbonate mounds of the Petit-Mont Member corresponded to adaptation of communities to decreasing depth, from intermittent agitation to turbulence. The more general model of Walker and Alberstadt (1975) distinguished a succession of phases in the evolution of mound communities, from stabilization of the substrate until domination by some very specialized species. In the case of "Les Wayons" and "St.Rémy" mounds, the colonization of the substrate is related to sponges (PM1); for "Les Bulants" type, to sponges and lamellar corals (PM2). The diversification phase corresponded to the establishment of an assemblage of corals, crinoids, brachiopods, stromatoporoids and cyanobacteria (PM3), followed by branching tabulate corals, brachiopods and green algae (PM4). The domination stage is marked by the appearance of grey limestone with corals, stromatoporoids, thrombolites and microbial mats (PM5), with general encrusting morphology. In off-mound environments, however (Neuville sections), no apparent change in facies and assemblages (E2) is observed. This appears to exclude the intervention of allogenic processes in the evolution of mound communities; however, off-mounds communities are mainly made up of generalists of which the sensitivity to variations of oceanic parameters is less than that of more specialized organisms (Walker and Alberstadt, 1975). Furthermore, various sedimentological features (see above) indicate an increase in turbulence and luminosity when passing from the base of the mounds to grey limestone (PM5). In the internal zones of the platform (Aisemont Formation, Fig. 8), the shallowing upward succession of facies was a response to a relative sea-level fall (Boulvain and Coen-Aubert, 1989). Biostratigraphic correlations (conodonts and rugose corals) show that the shallowest oncoidal facies of the Aisemont Formation are contemporaneous with the development of PM5 in the mounds of the Philippeville Anticline. PM5 development is also accompanied (e.g., at Beauchâteau), by an increase in the diameter of the mounds and by progradation of lateral facies PM3 down flanks. These arguments suggest that at least the development of the grey algal-microbial core (PM5) in mounds of the Philippeville Anticline was related to a relative sealevel fall (Boulvain and Herbosch, 1996). Near the southern border of the Dinant Synclinorium, the "St.Rémy" carbonate mounds did not develop this facies succession and thus did not record this relative sealevel fall, probably because they formed in deeper water.

If ecological evolution (PM1 to PM5) of the mounds of the Philippeville Anticline is related to bathymetry, a similar interpretation for the opposite sequence (PM5 to PM2) which caps, after a hardground (Plate 2D), the "Les Wayons" mounds could be suggested. This sequence, related to increasing depth, is accompanied by an upward reduction in the diameter of the carbonate mounds. A specialized 
community of corals, stromatoporoids, thrombolites and microbial mats (PM5) was replaced by a community of sponges, corals and crinoids (PM2). How- ever, carbonate production was not able to compensate for the rise in sea level, and the last beds of the mounds, already very argillaceous, were covered by

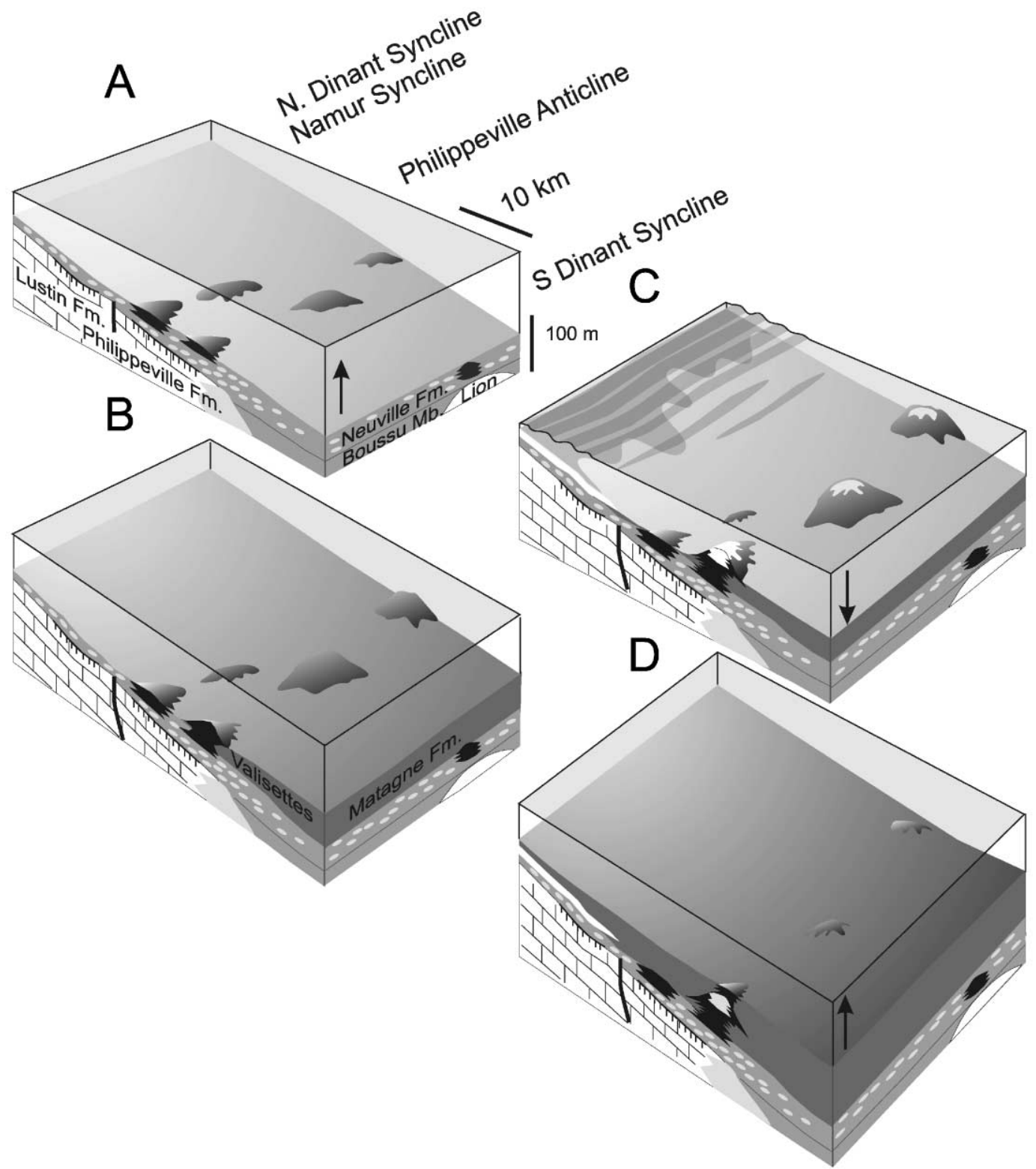

Fig. 11. Paleogeographic evolution of the Frasnian sedimentation basin in the Dinant and Namur Synclines, during the upper part of the Frasnian. (A) Drowning of the Middle Frasnian carbonate shelf and initiation of carbonate mound development in the Neuville Formation. (B) Deposition of the first shale of the Valisettes Formation and morphological differentiation between "Les Bulants" and "Les Wayons" type carbonate mounds. (C) Development of cryptalgal facies in the littoral area and of PM5 on the top of the Petit-Mont Member mounds during a sea-level fall. (D) Late Frasnian marine transgression with progressive drowning of carbonate mounds. 
argillaceous limestone and nodular shale (Plate 2E). This transgressive sequence is marked in the internal zones of the platform by the disappearance of oncoid shoals and overall deposition of argillaceous sediment (Fig. 11).

Grey limestone with fenestrae, branching tabulate corals and brachiopods (PM4) are developed when mounds reached the wave action and photic zones. Depth of the wave action and photic zones may be related to the geometrical characteristics of the basin, to climatic and other parameters. About $30 \mathrm{~m}$ is used here as a base (Flügel, 1982). Using this depth of development for facies PM4, it is possible to estimate the depth of development of red limestone with stromatactis (PM1) by knowing the average thickness of decompacted sediments separating both facies. An average rate of compaction of 1.5 (Boulvain, 1993) was estimated by the method of Beaudoin et al. (1987). Calculation gives a value of about 100-150 $\mathrm{m}$ for water depth during deposition of the base of the mounds.

\subsection{Origin of cements}

Interpretation of the origin of cements of the carbonate mounds must integrate petrographic and geochemical data and results of the sedimentological study which provide constraints on the evolution of the environment of sedimentation.

(1) Radiaxial calcite. The origin of this cement was the subject of a sharp controversy between the supporters of a secondary origin, by replacement of primary fibrous marine cement (Kendall and Tucker, 1973; Kerans et al., 1986), and supporters of direct precipitation from sea water (Kendall, 1985; Saller,
1986). In the carbonate mounds of the Petit-Mont Member, this cement, though fibrous, does not have the isotopic signature of marine Devonian cement $\left(\delta^{18} \mathrm{O}:-5.0 \%\right.$ PDB; $\delta^{13} \mathrm{C}:+2.0 \%$ PDB, Carpenter and Lohmann, 1989), or the high percentage of $\mathrm{Mg}$ of recent magnesian calcite (Table 4). Its morphology, however, is very close to HMC and common interstratification of cement and marine sediment point to its early formation. SEM reveals $\mu \mathrm{m}$-scale dolomite crystals after acid etching. Fig. 12 shows that radiaxial calcite has the same isotopic signature as nonluminescent automorphic calcite (2). Consequently, radiaxial calcite is probably a former magnesian marine cement, isotopically and chemically rebalanced by low magnesian water responsible for the precipitation of the following stage.

Cements (2) and (3) were either of meteoric origin, or were produced during the evolution of burial water. Isotopic values and luminescence support a meteoric origin (Mountjoy and Krebs, 1983; Carpenter and Lohmann, 1989; Hurley and Lohmann, 1989). The sequence (2)-(3) can then be interpreted as a result of increase in the reducing character of meteoric fluids, allowing the incorporation of $\mathrm{Mn}$ in the network of calcite (Table 4, Fig. 13) (cf. Mountjoy and Krebs, 1983; Miller, 1986).

(4) Xenomorphic calcite with dull orange luminescence testifies, by its high Fe content, of more reducing conditions than stage (3). Introduced into the cavities by a network of fractures, this cement represents more than $50 \%$ of the volume of cement of mounds. Its strongly negative $\delta^{18} \mathrm{O}$ values point to an increase in the temperature of diagenetic fluids. The correlative reduction in $\delta^{13} \mathrm{C}$ can be related to a disappearance of metastable carbonates. This cement

Table 4

$\mathrm{FeO}, \mathrm{MnO}, \mathrm{MgO}$ and $\mathrm{CaO}$ contents, as well as $\delta^{13} \mathrm{C}(\mathrm{PDB})$ and $\delta^{18} \mathrm{O}(\mathrm{PDB})$ of the various types of cements and of the matrix

\begin{tabular}{|c|c|c|c|c|c|c|c|c|c|c|c|c|c|c|c|}
\hline \multirow[t]{2}{*}{ Analyses } & \multicolumn{3}{|c|}{$\begin{array}{l}\text { Radiaxial } \\
\text { cement (1) }\end{array}$} & \multicolumn{3}{|c|}{$\begin{array}{l}\text { Nonluminescent } \\
\text { calcite (2) } \\
\end{array}$} & \multicolumn{3}{|c|}{$\begin{array}{l}\text { Luminescent } \\
\text { calcite (3) }\end{array}$} & \multicolumn{3}{|c|}{ Fe-calcite (4) } & \multicolumn{3}{|c|}{ Matrix } \\
\hline & $n$ & Mean & Variance & $n$ & Mean & Variance & $n$ & Mean & Variance & $n$ & Mean & Variance & $n$ & Mean & Variance \\
\hline $\mathrm{FeO}(\%)$ & 6 & - & - & 5 & - & - & 6 & - & - & 5 & 1.0 & 0.1 & 6 & 0.8 & 0.2 \\
\hline $\mathrm{MnO}(\%)$ & 6 & - & - & 5 & - & - & 6 & 1.5 & 0.5 & 5 & 0.08 & 0.05 & 6 & - & - \\
\hline $\mathrm{MgO}(\%)$ & 6 & 1.2 & 0.3 & 5 & 1.0 & 0.1 & 6 & 0.8 & 0.1 & 5 & 1.1 & 0.2 & 6 & 1.5 & 0.3 \\
\hline $\mathrm{CaO}(\%)$ & 6 & 98.4 & 0.8 & 5 & 98.8 & 0.7 & 6 & 96.8 & 0.5 & 5 & 97.0 & 0.6 & 6 & 94.7 & 0.8 \\
\hline $\mathrm{SrO}(\%)$ & 6 & - & - & 5 & 0.1 & 0.04 & 6 & - & - & 5 & 0.08 & 0.05 & 6 & - & - \\
\hline$\delta^{13} \mathrm{C}(\mathrm{PDB})$ & 8 & 1.69 & 1.4 & 8 & 2.87 & 1.1 & & & & 13 & 2.24 & 1.5 & 15 & 1.94 & 1.5 \\
\hline$\delta^{18} \mathrm{O}(\mathrm{PDB})$ & 8 & -8.02 & 1.1 & 8 & -7.70 & 0.6 & & & & 13 & -10.86 & 1.0 & 15 & -10.85 & 1.8 \\
\hline
\end{tabular}




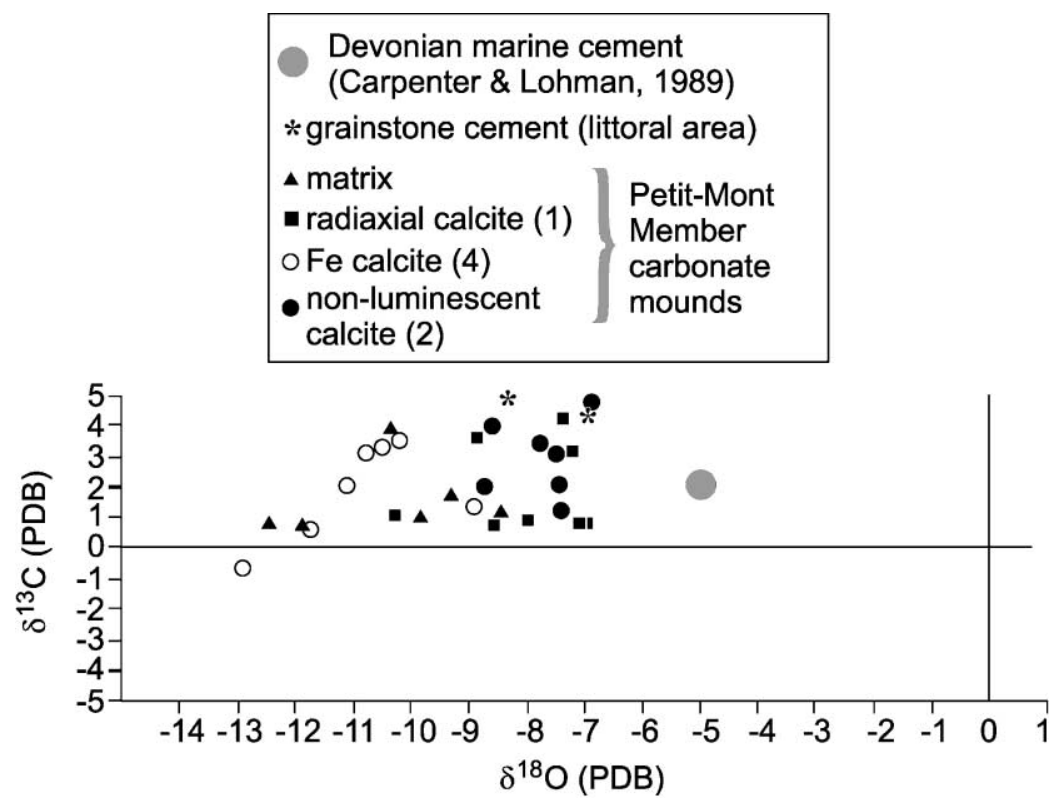

Fig. 12. Plot of $\delta^{13} \mathrm{C}(\mathrm{PDB}) / \delta^{18} \mathrm{O}(\mathrm{PDB})$ of the various types of cements and of the matrix of Petit-Mont Member carbonate mounds. Devonian marine cement after Carpenter and Lohmann (1989).

is related to burial (Mountjoy and Krebs, 1983; Carpenter and Lohmann, 1989; Savard and Bourque, 1989). The matrix was intensely neomorphosed during this stage of cementation: its luminescence and its isotopic composition are the same as those of stage (4) (Fig. 12).

(5) Saddle dolomite was a late diagenetic stage that formed during or after stage (4) calcite. It was related to burial (Mountjoy and Krebs, 1983).

\subsection{Diagenetic sequences and postsedimentary evolution}

Diagenesis began with marine HMC cementation in the "large" cavities. After drowning of mounds, a meteoric oxidizing aquifer is developed, with intense circulation and strong cementation in the internal zones of the platform, close to the surfaces of recharge (Lustin, Crupet, Aisemont, Huccorgne). In

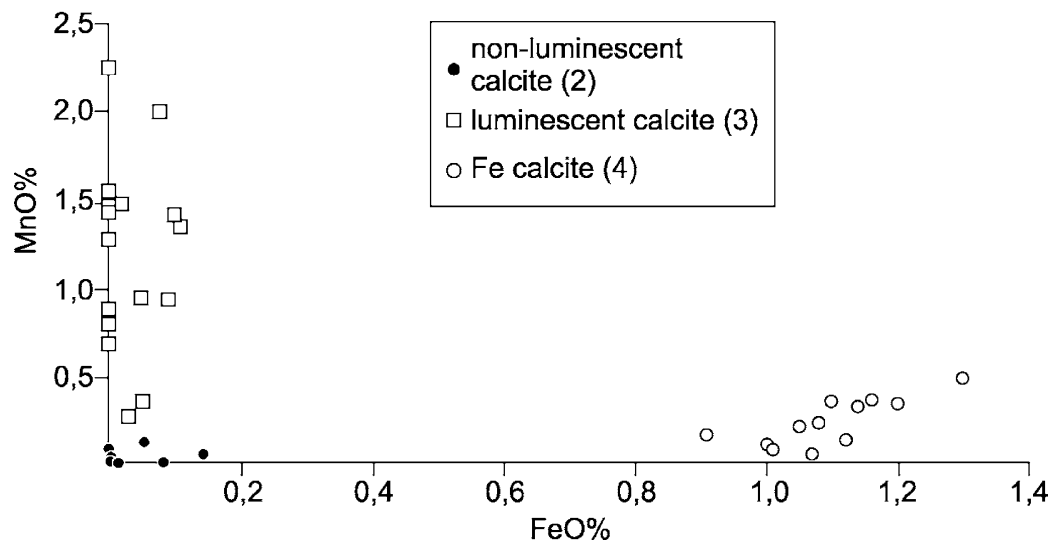

Fig. 13. Relationship between chemical composition and luminescence of calcites. 


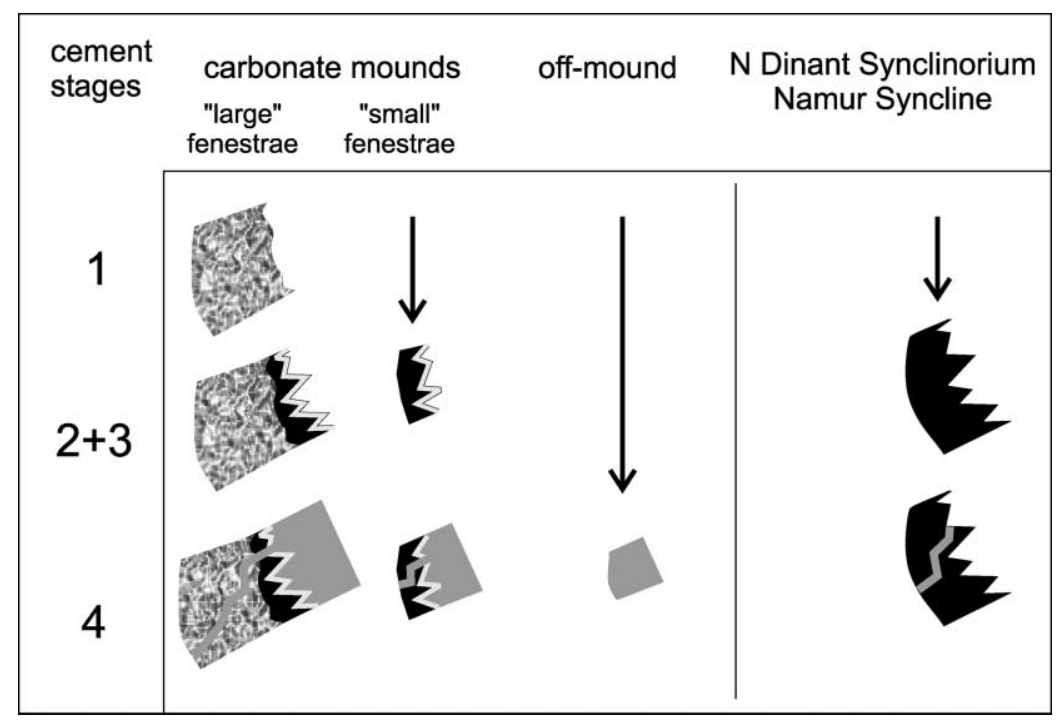

Fig. 14. Diagenetic sequences in function of paleogeography.

carbonate mounds, only a thin calcite fringe (2) precipitated, with the same isotopic composition as the cements of the littoral grainstone (Figs. 12, 14). This calcite (2) was followed in the carbonate mounds by a more reducing cement (3). Stage (3) was not precipitated in the littoral zones. The invasion of the sediments by a meteoric lens was induced by a significant marine regression during the Famennian. Cements (4) and (5) were produced during the onset of pressure solution. The hot and reducing fluids responsible for the precipitation of iron-bearing cement circulated through a network of fractures open on a basin scale.

\section{Conclusions}

Frasnian carbonate mounds from the Petit-Mont Member offer an ideal case study of the architecture of carbonate mounds according to bathymetric evolution. Above a substrate of argillaceous limestone rich in sponges, corals, brachiopods and bryozoans, red limestone with stromatactis (PM1) initiated mound development. This facies was produced by a community of sponges and iron bacteria, below the photic and wave action zones, in a hypoxic environment, at a depth of 100-150 m. Above this, a transition towards red limestone with stromatactis, corals and crinoids
(PM2), then to pink limestone with corals, crinoids, brachiopods, stromatactis, fenestrae and stromatoporoids (PM3) occurred. The photic zone was reached for cyanobacteria. Grey limestone with fenestrae, branching tabulate corals and brachiopods (PM4) are developed in the wave action zone. At the same time, grey limestone with corals, stromatoporoids, thrombolites and microbial mats was deposited in the mound core (PM5), marking the domination of encrusting organisms. The relationships between the accumulation rate of sediments in the off-mound environment and the buildups' growth rate governed the morphology of the carbonate mounds, but did not affect the nature of facies and the succession of communities.

The facies of Petit-Mont Member mounds are indicators of palaeobathymetry. They also point to a particular palaeoceanography. They recorded hypoxic environments, possibly preceding a large-scale anoxic event: the Lower Kellwasser event. Can we consequently consider this type of carbonate mound as an indicator of palaeoceanographic changes on a large scale? Other case studies could test this hypothesis.

The postsedimentary evolution of the mounds shows a typical diagenetic sequence, common to all the Petit-Mont Member mounds and identical to diagenetic sequences of other Palaeozoic carbonate mounds and banks (Miller, 1986, Lees and Miller, 1995): cementation in the marine phreatic zone pre- 
liminary to the drowning, then development of a meteoric lens at the time of a marine regression, with reduced facies in the distal zones of the aquifer and, finally, burial cementation during tectonism.

\section{Acknowledgements}

I am grateful to all those who shared their remarks and observations when visiting the Belgian Frasnian mounds. I also thank Fritz Neuweiler for his comments and corrections on a first version of this manuscript. Suggestions from Alex Cook, Carl W. Stock and an anonymous reviewer improved this paper very much. I am especially thankful to the editors David C. Kopaska-Merkel and Douglas W. Haywick for comments and great linguistic help.

\section{References}

Beaudoin, B., Cojan, I., Fries, G., Maillart, J., Parize, O., Pinault, M., Pinoteau B., Truyol V., 1987. Mesure directe de la compaction dans les sédiments. In: Aissaoui, D.M., et al. (Eds.), Genèse et Evolution des Bassins sédimentaires. Notes Mem. Total CFP 21, 235-247.

Bosence, D.W.J., Bridges, P., 1995. Origin and evolution of carbonate mud-mounds. In: Monty, C.L.V., Bosence, D.W.J., Bridges, P.H., Pratt, B.R. (Eds.), Carbonate Mud-Mounds: Their Origin and Evolution. Int. Assoc. Sedimentol., Spec. Publ., vol. 23, pp. 3-9.

Boulvain, F., 1993. Sédimentologie et diagenèse des monticules micritiques "F2j" du Frasnien de l'Ardenne. Serv. Géol. Belg. Prof. Pap. (2), 260, 427 pp.

Boulvain, F., Coen-Aubert, M., 1989. Modèle sédimentologique des monticules micritiques de la partie supérieure du Frasnien du Massif de Philippeville et corrélations séquentielles avec le bord nord du Synclinorium de Dinant (Belgique). C. R. Acad. Sci. Paris 309 (II), 81-87.

Boulvain, F., Herbosch, A., 1996. Anatomie des monticules micritiques du Frasnien belge et contexte eustatique. Bull. Soc. Géol. Fr. 167 (3), 391-398

Boulvain, F., Herbosch, A., Keppens, E., 1992. Diagenèse des monticules micritiques de la partie supérieure du Frasnien du Synclinorium de Dinant (Belgique, France). C. R. Acad. Sci. Paris 315 (II), 551-558.

Boulvain, F., Bultynck, P., Coen, M., Coen-Aubert, M., Lacroix, D., Laloux, M., Casier, J.-G., Dejonghe, L., Dumoulin, V., Ghysel, P., Godefroid, J., Helsen, S., Mouravieff, N., Sartenaer, P., Tourneur, F., Vanguestaine, M., 1999. Les Formations du Frasnien de la Belgique. Mem. Geol. Surv. Belgium 44, 125 pp.

Bourque, P.-A., 1997. Paleozoic finely crystalline carbonate mounds: cryptic communities, petrogenesis and ecological zonation. Facies 36, 250-253.

Bourque, P.-A., Boulvain, F., 1993. A model for the origin and petrogenesis of the red stromatactis limestone of Paleozoic carbonate mounds. J. Sediment. Petrol. 63 (4), 607-619.

Bridges, P.H., Chapman, A., 1988. The anatomy of a deep-water mud-mound complex to the southwest of the Dinantian platform in Derbyshire, UK. Sedimentology 35, 139-162.

Bultynck, P., Helsen, S., Hayduckiewich, J., 1998. Conodont succession and biofacies in upper Frasnian formations (Devonian) from the southern and central parts of the Dinant Synclinorium (Belgium) - (Timing of facies shifting and correlation with Late Frasnian events). Bull. Inst. R. Sci. Nat. Belg., Sci. Terre $68,25-75$.

Burchette, T.P., 1981. European Devonian reefs: a review of current concepts and models. In: Toomey, D.F. (Ed.), European Fossil Reef Models. Soc. Econ. Paleontol. Mineral., Spec. Publ., vol. 30 , pp. $85-142$.

Byers, C.W., 1977. Biofacies patterns in euxinic basins: a general model. In: Cook, H.E., Enos, P. (Eds.), Deep-Water Carbonate Environments. Soc. Econ. Paleontol. Mineral., Spec. Publ., vol. 25 , pp. $5-17$.

Carpenter, S.J., Lohmann, K.C., 1989. $\delta^{18} \mathrm{O}$ and $\delta^{13} \mathrm{C}$ variations in Late Devonian marine cements from the Golden Spike and Nevis Reefs, Alberta. Canada. J. Sediment. Petrol. 59 (5), $792-814$.

Cayeux, L., 1935. Les Roches Sédimentaires de France. Roches Carbonatées (Calcium et Dolomies). Masson, 436 pp.

Coen, M., Coen-Aubert, M., Cornet, P., 1977. Distribution et extension stratigraphique des récifs à "Phillipsastrea" dans le Frasnien de l'Ardenne. Ann. Soc. Géol. Nord XCVI (4), 325-331.

Coen-Aubert, M., 1982. Rugueux solitaires du Frasnien de la Belgique. Bull. Inst. R. Sci. Nat. Belg., Sci. Terre 54, 65 pp.

Cowen, J.P., Silver, M., 1984. The association of iron and manganese with bacteria on marine macroparticulate material. Science 224, 1340-1342.

Cuffey, R.J., 1977. Bryozoan contributions to reefs and bioherms through geologic time. In: Frost, S.H., Weiss, M.P., Saunders, J.B. (Eds.), Reefs and Related Carbonates-Ecology and Sedimentology. Am. Assoc. Pet. Geol., Stud. Geol., vol. 4, pp. $181-194$.

Delhaye, F., 1913. Etude de la formation des récifs de calcaire rouge à Acervularia et Hypothyris cuboïdes. Ann. Soc. Géol. Belg. XL, B469-B481.

Dewalque, G., 1868. Prodrome d'une description géologique de la Belgique. Liège, Imp. Carmanne, 442 pp.

Dumon, P., 1932. Compte rendu de l'excursion du 11 juin 1932 aux carrières de marbre rouge de Vodelée et de Soulme. Bull. Soc. Belge Géol. XLII, 118-128.

Fischer, A.G., 1964. The Lofer cyclothem of the Alpine Triassic. Kans. Geol. Surv. Bull. 169, 107-149.

Flügel, E., 1982. Microfacies Analysis of Limestones. SpringerVerlag, Berlin, 633 pp.

Ghiorse, W.C., 1984. Biology of iron- and manganese-depositing bacteria. Annu. Rev. Microbiol. 38, 515-550.

Hurley, N.F., Lohmann, K.C., 1989. Diagenesis of Devonian reefal carbonates in the Oscar Range, Canning Basin, Western Australia. J. Sediment. Petrol. 59 (1), 127-146. 
Kendall, A.C., 1985. Radiaxial fibrous calcite: a reappraisal. In: Schneidermann, N., Harris, P.M. (Eds.), Carbonate Cements. Soc. Econ. Paleontol. Mineral., Spec. Publ., pp. 59-77.

Kendall, A.C., Tucker, M.E., 1973. Radiaxial fibrous calcite: a replacement after acicular carbonate. Sedimentology 20, $365-389$.

Kerans, C., Hurley, N.F., Playford, P.E., 1986. Marine diagenesis in Devonian reef complexes of the Canning Basin, Western Australia. In: Schroeder, J.H., Purser, B.H. (Eds.), Reef Diagenesis. Springer-Verlag, Berlin, pp. 357-380.

Lecompte, M., 1936. Contribution à la connaissance des "récifs" du Frasnien de l'Ardenne. Mém. Inst. Géol. UCL X, 30-113.

Lecompte, M., 1959. Certain data on the genesis and ecologic character of Frasnian reefs of the Ardennes (transl. by P.F. Moore). Int. Geol. Rev. 1 (7), 1-23.

Lees, A., Miller, J., 1985. Facies variation in Waulsortian buildups: Part 2. Mid-Dinantian buildups from Europe and North America. Geol. J. 20, 159-180.

Lees, A., Miller, J., 1995. Waulsortian banks. In: Monty, C.L.V., Bosence, D.W.J., Bridges, P.H., Pratt, B.R. (Eds.), Carbonate Mud-Mounds: Their Origin and Evolution. Int. Assoc. Sedimentol., Spec. Publ., vol. 23, pp. 191-271.

Lohmann, K.C., Meyers, W.J., 1977. Microdolomite inclusions in cloudy prismatic calcites: a proposed criterion for former highmagnesium calcites. J. Sediment. Petrol. 47 (3), 1078-1088.

Maillieux, E., 1913. Nouvelles observations sur le Frasnien et en particulier sur les paléorécifs de la plaine des Fagnes. Bull. Soc. Belge Géol. XXVII, 67-104.

Maillieux, E., 1926. Contribution à l'étude du "Massif" de Philippeville. Bull. Soc. Belge Géol., Paléontol. Hydrol. 36, 86-112.

Mamet, B., Boulvain, F., 1988. Remplissage bactérien de cavités biohermales frasniennes. Bull. Soc. Belge Géol. 97, 63-76.

Mamet, B., Boulvain, F., 1992. Microflore des monticules frasniens "F2j" de Belgique. Rev. Micropaléontol. 35 (4), 283-302.

Maurin, A.F., Philip, J., Brunel, P., 1981. Possible microbial accretions in Cenomanian mounds, S.E. France. In: Monty, C.L.V. (Ed.), Phanerozoic Stromatolites. Springer-Verlag, Berlin, pp. $121-133$.

Miller, J., 1986. Facies relationships and diagenesis in Waulsortian mudmounds from the Lower Carboniferous of Ireland and N. England. In: Schroeder, J.H., Purser, B.H. (Eds.), Reef Diagenesis. Springer-Verlag, pp. 311-335.

Monty, C.L.V., 1995. The rise and nature of carbonate mudmounds: an introductory actualistic approach. In: Monty C.L.V., Bosence, D.W.J., Bridges, P.H., Pratt, B.R. (Eds.), Carbonate Mud-Mounds: Their Origin and Evolution. Int. Assoc. Sedimentol., Spec. Publ., vol. 23, pp. 11-48.

Monty, C.L.V., Van Laer, P., 1988. The Upper Devonian mud mounds from the south western Dinant Synclinorium. In: Herbosch, A. (Ed.), 9th IAS Eur. Reg. Meeting on Sedimentology Excursion Guidebook, pp. 157-176.

Monty, C.L.V., Bernet-Rollande, M.C., Maurin, A.F., 1982. Re-interpretation of the Frasnian classical "reefs" of the southern Ardennes, Belgium. (Extended abstract). Ann. Soc. Géol. Belg. 105, 339-341.

Mountjoy, E.W., Krebs, W., 1983. Diagenesis of Devonian reefs and buildups, Western Canada and Europe-a comparison. Z. Dtsch. Geol. Ges. 134, 5-60.

Mountjoy, E.W., Riding, R., 1981. Foreslope stromatoporoid-renalcid bioherm with evidence of early cementation, Devonian Ancient Wall reef complex, Rocky Mountains. Sedimentology 28 (3), 299-320.

Nealson, K.H., 1983. The microbial iron cycle. In: Krumbein, W.E. (Ed.), Microbial Geochemistry. Blackwell Sci. Publ., Oxford, pp. $159-191$.

Playford, P.E., 1981. Devonian Reef Complexes of the Canning Basin Western Australia. Field Excursion Guidebook. 5th Austr. Geol. Conv., Geol. Soc. Aust., 64 pp.

Playford, P.E., 1984. Platform-margin and marginal-slope relationships in Devonian Reef complexes of the Canning Basin. The Canning Basin, W.A. Proc. Geol. Soc. Aust. and Pet. Explor. Soc. Aust. Symp., Perth, Australia, pp. 190-214.

Pratt, B.R., 1982. Stromatolitic framework of carbonate mudmounds. J. Sediment. Petrol. 52 (4), 1203-1227.

Pratt, B.R., 1995. The origin, biota and evolution of deep-water mudmounds. In: Monty, C.L.V., Bosence, D.W.J., Bridges, P.H., Pratt B.R. (Eds.), Carbonate Mud-Mounds: Their Origin and Evolution. Int. Assoc. Sedimentol., Spec. Publ., vol. 23, pp. 49-123.

Pratt, B.R., James, N.R., 1982. Cryptalgal-metazoan bioherms of Early Ordovician age in the St. George Group, western Newfoundland. Sedimentology 29 (4), 543-571.

Pringsheim, E.G., 1952. Organismes ferrugineux. Endeavour XI (44), 208-214.

Reijers, T.J.A., 1984. Devonian carbonate facies patterns in the Dinant Synclinorium, Belgium. Geol. Mijnbouw 0016, 19-29.

Saller, A.H., 1986. Radiaxial calcite in Lower Miocene strata, subsurface Enewetak atoll. J. Sediment. Petrol. 56 (6), 743-762.

Savard, M., Bourque, P.-A., 1989. Diagenetic evolution of a Late Silurian reef platform, Gaspé Basin, Quebec, based on cathodoluminescence petrography. Can. J. Earth Sci. 26 (4), 791-806.

Termier, H., Termier, G., Tsien, H.H., 1981. Spongiaires des calcaires récifaux du Frasnien de l'Ardenne. Bull. Soc. Belge Géol. 90 (4), 287-298.

Tourneur, F., 1982. Conodontes de trois "récifs de marbre rouge F2j”. Stratigraphie et écologie. Bull. Soc. Belge Géol. 91 (2), 91-102.

Tsien, H.H., 1975. Introduction to the Devonian reef development in Belgium. 2nd Symp. Int. Coraux et Récifs Coralliens Fossiles, Paris, Livret-Guide Exc. C, pp. 3-43.

Tsien, H.H., 1980. Les régimes récifaux dévoniens en Ardenne. Bull. Soc. Belge Géol. 89 (2), 71-102.

Tsien, H.H., 1985. Algal-bacterial origin of micrites in mud mounds. In: Toomey, D.F., Nitecki, M.H. (Eds.), Paleoalgology: Contemporary Research and Applications. Springer-Verlag, Berlin, pp. 291-296.

Van Veen, W.L., Mulder, E.G., Deinema, M.H., 1978. The Sphaerotilus-Leptothrix group of bacteria. Microbiol. Rev., 329-356.

Walker, K.R., Alberstadt, L.P., 1975. Ecological succession as an aspect of structure in fossil communities. Paleobiology 1 , 238-257.

Wallace, M.W., 1987. The role of internal erosion and sedimentation in the formation of Stromatactis mudstones and associated lithologies. J. Sediment. Petrol. 57 (4), 695-700. 